\title{
Biochemical Properties and Subcellular Distribution of the Neuronal Class E Calcium Channel $\alpha_{1}$ Subunit
}

\author{
Charles T. Yokoyama, ${ }^{1,2}$ Ruth E. Westenbroek, ${ }^{1}$ Johannes W. Hell, ${ }^{1}$ Tuck Wah Soong, ${ }^{3}$ Terry P. Snutch, ${ }^{3}$ and \\ William A. Catterall ${ }^{1}$ \\ 'Department of Pharmacology and ${ }^{2}$ Graduate Program in Neurobiology, University of Washington, Seattle, \\ Washington 98195 and ${ }^{3}$ Biotechnology Laboratory and Departments of Zoology and Neuroscience, University of \\ British Columbia, Vancouver, British Columbia V6T1W5, Canada
}

\begin{abstract}
Anti-peptide antibodies specific for the neuronal calcium channel $\alpha_{1 E}$ subunit (anti-CNE1 and anti-CNE2) were produced to study the biochemical properties and subcellular distribution of the $\alpha_{1 E}$ polypeptide from rat brain. Immunoblotting identified a single size form of 245-255 kDa which was a substrate for phosphorylation by CAMP-dependent protein kinase, protein kinase C, cGMP-dependent protein kinase, and calcium/calmodulin-dependent protein kinase II. Ligand-binding studies of $\alpha_{1 \mathrm{E}}$ indicate that it is not a high affinity receptor for the dihydropyridine isradipine or the peptide toxins $\omega$-conotoxin GVIA or $\omega$-conotoxin MVIIC at concentrations which elicit high affinity binding to other channel types in the same membrane preparation. The $\alpha_{1 E}$ subunit is widely distributed in the brain with the most prominent immunocytochemical staining in deep midline structures such as caudate-putamen, thalamus, hypothalamus, amygdala, cerebellum, and a variety of nuclei in the ventral midbrain and brainstem. Staining is primarily in the cell soma but is also prominent in the dendritic field of a discrete subset of neurons including the mitral cells of the olfactory bulb and the distal dendritic branches of the cerebellar Purkinje cells. Our observations indicate that the 245-255 $\mathrm{kDa} \alpha_{1 \mathrm{E}}$ subunit is localized in cell bodies, and in some cases in dendrites, of a broad range of central neurons and is potentially modulated by multiple second messenger-activated protein kinases.
\end{abstract}

[Key words: ion channel, calcium channel, phosphorylation, peptide toxin, imunocytochemistry, Purkinje cell]

Received Feb. 17, 1995; revised May 8, 1995; accepted May 22, 1995.

We thank Drs. Eric I. Rotman and Brian J. Murphy (University of Washington. Seattle) for providing PKA and PKC, Drs. Dehra A. Brickey and Tom Soderling (Vollum Institute, Portland OR) for providing Cam KII, and Drs. Andreas Woppmann and George W. Miljanich (Neurex Corporation, Menlo Park, CA) for generously supplying ${ }^{125}[-(1-C T x$ MVIIC. Peptides were synthesized in the Molecular Pharmacology Facility, Department of Pharmacology, University of Washington. Confocal microscopy was carried out in the Imaging Facility of the W. M. Keck Center for Advanced Studies of Neural Signaling University of Washington. This investigation was supported by NIH Research Grant R01 NS22625 to W.A.C., by a predoctoral fellowship from NIH Grant T32 GM07108-19 to C.T.Y., by Pfizer, Inc., and the W. M. Keck Foundation, and by grants from the Medical Research Council of Canada and the Howard Hughes Medical Institute International Research Scholars Program to T.P.S. T.P.S. is a recipient of a fellowship from the Alfred P. Sloan Research Foundation. J.W.H. was a recipient of a postdoctoral fellowship fron the Deutsche Forschungsgemeinschaft (HE 1784/2-1)

Correspondence should be addressed to William A. Catterall at the above address.

Copyright (C) 1995 Society for Neuroscience $0270-6474 / 95 / 156419-14 \$ 05.00 / 0$
Voltage-gated calcium channels regulate $\mathrm{Ca}^{2+}$ entry in excitable cells and control many aspects of cellular function (McCleskey, 1994). In neurons, these functions include the regulation of neurotransmitter release, modulation of firing patterns and excitability, and activation of compartment-specific signaling networks. Five types of calcium current, termed T, L, N, P, and Q, have been previously described based on physiological and pharmacological criteria (Bean, 1989; Tsien et al., 1991; Snutch and Reiner, 1992; Zhang, 1993). T-Type calcium currents activate at low voltage, inactivate quickly, and are blocked by relatively low concentrations of $\mathrm{Ni}^{2+}$ but not by organic or peptide calcium channel blockers. L-Type calcium currents are high-voltage-activated, slowly inactivated by sustained depolarization, and specifically blocked by dihydropyridines: N-, P-, and Q-type calcium currents are also high-voltage-activated, have variable rates of inactivation, and are preferentially blocked by the peptide neurotoxins $\omega$-conotoxin GVIA ( $\omega$-CTx GVIA), $\omega$-agatoxin IVA ( $\omega$-Aga IVA), and $\omega$-conotoxin MVIIC ( $\omega$-CTx MVIIC), respectively.

Calcium channels in neurons are multisubunit complexes containing the principal, pore-forming $\alpha_{1}$ subunits in association with auxiliary $\alpha_{2} \delta$ and $\beta$ subunits (reviewed in Isom et al., 1994), but the major physiological and pharmacological distinctions among voltage-gated calcium channels are primarily a reflection of the genetic diversity of the $\alpha_{1}$ subunits which are members of the structural superfamily of voltage-gated ion channels (Catterall, 1994). Five classes of $\alpha_{1}$ subunit cDNAs have been isolated from mammalian brain ( $\alpha_{1 \mathrm{~A}}$ through $\alpha_{1 \mathrm{E}}$, reviewed in Snutch and Reiner, 1992; Birnbaumer et al., 1994; Hofmann et al., 1994). A combination of functional expression and in vitro biochemistry indicates that $\alpha_{1 \mathrm{C}}$ and $\alpha_{\mathrm{ID}}$ are subunits of dihydropyridine-sensitive L-type channels (Hui et al., 1991; Snutch, 1991; Dubel et al., 1992; Williams, 1992a; Hell et al., 1993a). The $\alpha_{1 \mathrm{C}}$ and $\alpha_{1 \mathrm{D}}$ subunits are localized in the cell bodies and proximal dendrites of many classes of central neurons, and calcium entry through these channels is thought to regulate biochemical processes such as protein phosphorylation and gene expression (Morgan and Curran, 1986; Ahlijanian et al., 1990; Westenbroek et al., 1990; Murphy et al., 1991; Bading et al., 1993; Hell, 1993a). $\alpha_{1 \mathrm{~B}}$ is a subunit of $\omega$-CTx GVIA-sensitive N-type calcium channels (Dubel et al., 1992; Williams et al., 1992b; Fujita et al., 1993) which are localized in dendrites and presynaptic nerve terminals (Westenbroek et al., 1992) and can couple to neurotransmitter release in a variety of preparations (Hirning et al., 1988; Luebke et al., 1993; Takahashi and Mo- 
miyama, 1993; Turner et al., 1993; Wheeler et al., 1994). $\alpha_{1 \mathrm{~A}}$ is a subunit of calcium channels that are resistant to $\omega$-CTx-GVIA and sensitive to $\omega$-CTx MVIIC (Mori et al., 1991; Sather et al., 1993; Zhang et al., 1993; Stea et al., 1994a). Calcium channels containing $\alpha_{1 \mathrm{~A}}$ are located in dendrites and presynaptic nerve terminals (Westenbroek et al., 1993, 1995) and have been proposed to couple to neurotransmitter release at many synapses (Turner, 1992, 1993; Luebke et al., 1993; Takahashi and Momiyama, 1993; Wheeler et al., 1994).

The most recently described member of the calcium channel family is $\alpha_{1 \mathrm{E}}$ (Soong et al., 1993). Functional expression of $\alpha_{1 \mathrm{E}}$ with auxiliary subunits in Xenopus oocytes produced calcium channels which are rapidly inactivated and insensitive to high affinity organic and peptide calcium channel blockers (Soong et al., 1993; Williams et al., 1994; Randall et al., 1995). Wholecell voltage clamp and single channel recording studies of cerebellar granule cells have identified additional types of calcium currents which are resistant to dihydropyridines and $\omega$-CTXGVIA (R-type and G1-G3, respectively; Forti et al., 1994; Randall ct al., 1995). The currents conducted by $\alpha_{1 \mathrm{E}}$ are similar in some respects to T-type, R-type, and G2 calcium currents (Soong et al., 1993; Forti et al., 1994; Williams et al., 1994; Randall et al., 1995), but the precise relationship between $\alpha_{1 \mathrm{IE}}$ and native calcium currents remains to be defined.

Differential subcellular localization in cell bodies, dendrites, and nerve terminals is a critical determinant of the functional roles of neuronal calcium channels, but the biochemical properties and subcellular localization of the class E calcium channels are unknown. In this article, we report the biochemical characterization and immunocytochemical localization of calcium channels containing the $\alpha_{1 E}$ subunit. We identify $\alpha_{1 \mathrm{E}}$ polypeptides of 245-255 kDa which are phosphorylated in vitro by multiple protein kinases and exhibit a pharmacology and subcellular localization distinct from other known calcium channels.

\section{Materials and Methods}

Materials. ${ }^{3} \mathrm{H}$-Isradipine (PN200-1 10, $80 \mathrm{Ci} / \mathrm{mmol}$ ), ${ }^{125} \mathrm{I}-\omega$-CTx GVIA $(2200 \mathrm{Ci} / \mathrm{mmol})$, and $\gamma^{32} \mathrm{P}$ ATP $(3000 \mathrm{Ci} / \mathrm{mmol})$ were purchased from New England Nuclear-Du Pont (Boston, MA); the ECL detection kit for immunoblotting from Amersham Corp. (Arlington Heights, IL); digitonin from Gallard-Schlesinger (Carle Place, NY); and protein A-Sepharose (PAS), wheat-germ agglutinin-agarose (WGA), CNBr-activated Sepharose 4B, and bovine serum albumin (BSA; IgG free) from Sigma Chemical Corp. (St. Louis, MO). Controi rabbit IgG was obtained from Zymed Laboratories, Inc. (South San Francisco, CA). ${ }^{125}$ I- $\omega$-CTx MVIIC $(3000 \mathrm{cpm} / \mathrm{fmol})$ was generously supplied by Drs. A. Woppmann and G. W. Miljanich of Neurex Corp. (Menlo Park, CA). The catalytic subunit of PKA and PKC were purified by standard procedures (Kaczmarek et al., 1980; Woodgett and Hunter, 1987) and kindly provided by Drs. E. I. Rotman and B. J. Murphy, Department of Pharmacology, University of Washington, Seattle, WA 98195, Cam KII, expressed in $\mathrm{Sf} 9$ cells using a baculovirus expression vector and purified to homogeneity (Bricket et al., 1990), was generously supplied by Drs. D. A. Brickey and T. Soderling, Vollum Institute, Portland, OR, and PKG was purchased from Promega (Madison, WI). All other reagents were of standard biochemical quality from commercial sources. One and 2 month old Sprague-Dawley rats were obtained from Bantin and Kingman (Bellevue, WA).

Production and purification of peptides and antibodies. Anti-CNE 1 and anti-CNE2 were produced against two highly variable regions in the intracellular loop between domains II and III of the predicted polypeptide sequence based on the rbE-II cDNA clone (Soong et al., 1993), and anti-CP15 (anti-CP[1382-1400]) against the highly conserved region following the transmembrane segment IVS6 of the skeletal muscle and class C L-type $\alpha_{1}$ subunits (Striessnig et al., 1990). The 18 residue CNE1 and CNE2 peptides were synthesized corresponding to the se quences KYQLRRHMQMSSQEALNK (predicted residues 741-756 from rbE-II) and KYSASQERSLDEGVSIDG (residues 896-911), respectively. At the $\mathrm{NH}_{2}$-termini of each peptide, the residues lysine and tyrosine were added for the purpose of cross-linking to carrier protein and radiolabeling and are not part of the channel sequence. The peptide was synthesized by the solid-phase method (Merrifield, 1963), purified by reverse-phase high-pressure liquid chromatography on a Vydac 218 TP10 column, and confirmed by amino-acid analysis. The peptides were coupled with glutaraldehyde to bovine serum albumin (Orth, 1979), dialyzed against PBS, and emulsified in the same volume of Freund's complete (initial injection) or incomplete adjuvant. Injections were done at multiple subcutaneous sites on New Zealand White rabbits at 3 week intervals. Antisera were collected, titers determined by enzyme-linked immunosorbent assay (ELISA), and antibodies purified by affinity chromatography on CNE1, CNE2, or CP15 peptide coupled to CNBr-activated Sepharose. Briefly, $4 \mathrm{ml}$ of high-titer antiserum were adsorbed to the column matrix and incubated at $4^{\circ} \mathrm{C}$ overnight with mixing. The column was washed extensively with TBS (10 mM Tris-HCl, pH 7.4, $150 \mathrm{~mm} \mathrm{NaCl}, \mathrm{pH} 7.4)$ until the $\mathrm{A}_{280}$ of the eluate stabilized at less than 0.05 , and affinity-bound $\operatorname{IgG}$ was eluted with $2.8 \mathrm{M} \mathrm{MgCl}_{2}$, dialyzed against TBS, and concentrated with a Centriprep-30 apparatus (Amicon, Inc., Beverly, MA).

Partial purification of brain calcium channels. All extract incubations and manipulations were carried out at $4{ }^{\circ} \mathrm{C}$ or on ice to prevent proteolysis. In addition, the following protease inhibitors were included in all buffers: pepstatin $A$ and leupeptin (each at $1 \mu \mathrm{g} / \mathrm{ml}$ ), and aprotinin ( $2 \mu \mathrm{g} / \mathrm{ml}$ ), phenylmethanesulfonyl fluoride (PMSF, $0.2 \mathrm{mM}$ ), benzamidinc $(0.1 \mathrm{mg} / \mathrm{ml})$, and calpain inhibitors I and II $(8 \mu \mathrm{g} / \mathrm{ml})$. For each preparation, 15 rat brains were homogenized in $110 \mathrm{ml}$ of $320 \mathrm{~mm}$ sucrose with a glass-Teflon homogenizer (12 strokes at approximately $1000 \mathrm{rpm}$ ). The homogenate was separated at $5000 \mathrm{rpm}$ for $2 \mathrm{~min}$ in an SS34 rotor, and the supernatant (S1) was collected. Membranes were pelleted (P2) by centrifugation at $42,000 \mathrm{rpm}$ for $1 \mathrm{hr}$ in a $45 \mathrm{Ti}$ rotor and solubilized in $170 \mathrm{ml}$ of $1.2 \%$ digitonin, $300 \mathrm{mM} \mathrm{KCl}, 150 \mathrm{~mm}$

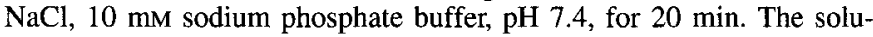
bilized P2 was subjected to centrifugation at $42,000 \mathrm{rpm}$ for $60 \mathrm{~min}$ in the $45 \mathrm{Ti}$ rotor to remove unsolubilized material. The supernatant (S3) was incubated for $1 \mathrm{hr}$ with $20 \mathrm{ml}$ of wheat-germ agglutinin-Sepharose, transferred to a column, and washed with $300 \mathrm{ml}$ of $0.1 \%$ digitonin, 75 $\mathrm{mm} \mathrm{NaCl}, 50 \mathrm{~mm}$ sodium phosphate, $10 \mathrm{~mm}$ Tris- $\mathrm{HCl}, \mathrm{pH} 7.4$, at a flow rate of $150 \mathrm{ml}$ per hour. The bound glycoproteins were eluted with wash buffer containing $100 \mathrm{~mm} N$-acetyl-D-glucosamine at a flow rate of $50 \mathrm{ml}$ per hour. Thirty $2 \mathrm{ml}$ fractions were collected, and the protein content of each fraction estimated from absorbance measurements at $A_{280}$. Peak $A_{280}$ fractions always corresponded to peak fractions for binding of PN200-110 and $\omega$-CTx GVIA, demonstrating the partial purification of both L-type and non-L-type calcium channel complexes. Eluted peak fractions were pooled, concentrated to $10 \%$ of the initial volume by centrifugation in a Centriprep-30 apparatus (Amicon, Inc., Beverly, MA), frozen in liquid $\mathrm{N}_{2}$, and stored at $-80^{\circ} \mathrm{C}$.

Immunoprecipitation and immunoblotting of calcium channels. All incubations and manipulations were carried out at $4^{\circ} \mathrm{C}$ or on ice and in the presence of protease inhibitors. Nonspecific sepharose-binding proteins were removed from the WGA-purified extract by incubating 0.2 $\mathrm{ml}$ of extract with $150 \mu \mathrm{l}$ of Sepharose CL-4B and $5 \mathrm{mg}$ of protein A Sepharose for $30 \mathrm{~min}$ with mixing, followed by a brief centrifugation to remove the Sepharose matrix. Calcium channels were concentrated from the WGA-purified extract by incubating the cleared WGA extract with $10 \mu \mathrm{g}$ of affinity-purified anti-CNE2 antibody or control rabbit $\mathrm{IgG}$ antibody for $1 \mathrm{hr}$ in a tilting mixer. Protein A-Sepharose $[2.5 \mathrm{mg}$, prewashed three times with phosphate-buffered saline (PBS; $10 \mathrm{~mm}$ $\mathrm{Na}_{2} \mathrm{HPO}_{4}, \mathrm{pH} 7.4,150 \mathrm{mM} \mathrm{NaCl}$ ), 0.5\% BSA, 0.1\% digitonin] was added, and the samples were incubated an additional $2 \mathrm{hr}$ with mixing. The resin was washed threc times in $1 \mathrm{ml}$ of $10 \mathrm{~mm}$ Tris-HCl, $\mathrm{pH} \mathrm{7.4,}$ $0.1 \%$ digitonin and two times in $10 \mathrm{~mm}$ Tris- $\mathrm{HCl}, \mathrm{pH} \mathrm{7.4}$, followed by extraction in $20 \mu \mathrm{l}$ of SDS sample buffer [125 mM Tris-HCl, $\mathrm{pH} 6.8$, $2 \%$ sodium dodecyl sulfate (SDS), 2 mM EDTA, $10 \%$ sucrose, $20 \mathrm{~mm}$ dithiothreitol (DTT), $1 \mu \mathrm{M}$ pepstatin A, $2 \mu \mathrm{g} / \mathrm{ml}$ leupeptin, $4 \mu \mathrm{g} / \mathrm{ml}$ aprotinin, $1 \mu \mathrm{M}$ p-nitrophenylphosphate] for $30 \mathrm{~min}$ at $50-60^{\circ} \mathrm{C}$ with mixing every 5 min. Samples were loaded onto a $5 \%$ SDS polyacrylamide gel with a 3\% stacking layer (Laemmli, 1970) and electrophoresed at $50 \mathrm{~mA} / \mathrm{gel}$ for $2-3 \mathrm{hr}$. The separated proteins were transfered electrophoretically to nitrocellulose filters and blocked for $1 \mathrm{hr}$ in blocking buffer consisting of $10 \%$ nonfat milk in TBS. Filters were then incubated with affinity-purified antibody $(50 \mu \mathrm{g}$ per $\mathrm{ml}$ in blocking buffer) for $1 \mathrm{hr}$, washed five times for 5 min each in blocking buffer, 
incubated $1 \mathrm{hr}$ with protein A-horseradish peroxidase, diluted 1:1000 in blocking buffer, washed $6 \times 10 \mathrm{~min}$ then $4 \times 30 \mathrm{~min}$ in TBS, and developed with the ECL reagent.

Immunoprecipitation and phosphorylation of calcium channels. Calcium channels were concentrated on protein A-Sepharose as described in the previous section. Prior to phosphorylation the resin was washed once in $1 \mathrm{ml}$ of basic phosphorylation buffer ( $50 \mathrm{mM}$ HEPES- $\mathrm{NaOH}$, $\mathrm{pH} 7.4,10 \mathrm{~mm} \mathrm{MgCl}_{2}, 1 \mathrm{~mm}$ EDTA, $0.1 \%$ digitonin, $1 \mu \mathrm{M}$ pepstatin). Phosphorylation reactions were performed in $50 \mu \mathrm{l}$ basic phosphorylation buffer with $0.5-1.0 \mu \mathrm{g}$ of cAMP-dependent protein kinase (PKA), protein kinase $\mathrm{C}$ (PKC), cGMP-dependent protein kinase (PKG), or calcium- and calmodulin-dependent protein kinase type II (Cam KII), along with $1 \mathrm{mM}$ DTT, $1 \mu \mathrm{M}$ pepstatin A, and $0.2 \mu \mathrm{M} \gamma^{32} \mathrm{P}$-ATP. The buffer was supplemented with $1.5 \mathrm{mM} \mathrm{CaCl}, 50 \mu \mathrm{g}$ of diolein, and 2.5 $\mathrm{mg}$ of phosphatidylserine for PKC; $2 \mu \mathrm{M}$ cGMP for PKG; and $1 \mu \mathrm{M}$ calinodulin and 0.6 IIIM $\mathrm{CaCl}_{2}$, withoul EGTA, for Cann KII. Incubations were at $32-34^{\circ} \mathrm{C}$ for $30 \mathrm{~min}$ with gentle mixing every $2 \mathrm{~min}$. The samples were washed twice with $0.1 \%$ digitonin in RIA buffer $(25 \mathrm{~mm}$ Tris-HCl, pH 7.4, $20 \mathrm{~mm}$ EDTA, $75 \mathrm{~mm} \mathrm{NaCl}, 20 \mathrm{~mm}$ Na-pyrophosphate, $20 \mathrm{mM} \beta$-glycerolphosphate, $50 \mathrm{~mm} \mathrm{NaF}$, and $1 \mathrm{~mm}$ $p$-nitrophenylphosphate), twice with $1 \%$ Triton X-100 in RIA buffer, and once in $10 \mathrm{~mm}$ Tris- $\mathrm{HCl}, \mathrm{pH} 7.4$. Proteins were extracted in SDS sample buffer for $30 \mathrm{~min}$ at $50-60^{\circ} \mathrm{C}$ and electrophoresed through a $5 \%$ SDS-polyacrylamide gel. For double immunoprecipitations, the washed Sepharose pellet following phosphorylation was incubated in $30 \mu \mathrm{l}$ of $50 \mathrm{~mm}$ Tris-HCl, pH 7.4, $1 \%$ SDS, $5 \mathrm{~mm}$ DTT, $20 \mathrm{~mm} \beta$-glycerol phosphate, $1 \mathrm{mM}$-nitrophenylphosphate, $1 \mu \mathrm{M}$ pepstatin $\mathrm{A}$, then diluted with $300 \mu \mathrm{l} 1 \%$ Triton X-100, 0.1\% BSA, $20 \mathrm{~mm} \beta$-glycerolphosphate, $1 \mathrm{mM} p$-nitrophenylphosphate, $1 \mu \mathrm{M}$ pepstatin A in RIA buffer and centrifuged. The supernatant was incubated with $25 \mu \mathrm{g}$ of affinity-purified antibody for $1.5 \mathrm{hr}$ at $4^{\circ} \mathrm{C}$ on a tilting mixer, $2 \mathrm{mg}$ of protein A-Sepharose were added, and the incubation was continued another $2.5 \mathrm{hr}$. Immunoprecipitated proteins were pelleted by centrifugation, washed three times with $1 \%$ Triton X-100 in RIA buffer, and once in $10 \mathrm{mM}$ Tris-HCl, pH 7.4, extracted in SDS sample buffer, separated by electrophoresis on a 5\% SDS-polyacrylamide gel, and visualized by autoradiography. For experiments with blocked antibodies, 10 $\mu \mathrm{M}$ of each peptide was added to the affinity-purified antibody for 30 min prior to incubation with the WGA extract.

Radioligand binding studies. For ${ }^{3} \mathrm{H}-\mathrm{PN} 200-110$ (isradipine) binding studies, the $110 \mathrm{ml}$ of $\mathrm{S} 1$ fraction was labeled with $5 \mu \mathrm{l}(5 \mu \mathrm{Ci}$ at 80 $\mathrm{Ci} / \mathrm{mmol}$ ) of ${ }^{3} \mathrm{H}-\mathrm{PN} 200-110$ at a final concentration of $0.57 \mathrm{nM}$ for $1 \mathrm{hr}$ on ice. The radioligand is stably bound thoughout the subsequent purification steps. Ten microliters of the WGA-purified preparation $(\sim 1000 \mathrm{cpm})$ was used for purification of calcium channel subtypes using $10-20 \mu \mathrm{g}$ of peptide affinity-purified antibodies anti-CNE1, anti$\mathrm{CNE} 2$, anti-CNC1 or control rabbit IgG. Immunoprecipitation was performed as described in the previous section. After the final wash, the antibody-bound Sepharose CL-4B matrix was transferred to vials for scintillation counting.

Total receptor-bound ${ }^{3} \mathrm{H}-\mathrm{PN} 200-110$ was determined by filter-binding assay. Briefly, $10 \mu \mathrm{l}$ of concentrated WGA column eluate was precipitated by incubation with $4 \mathrm{ml}$ of ice-cold $10 \%$ polyethylene glycol (PEG, average molecular weight 8000 ) in $10 \mathrm{mM} \mathrm{MgCl}_{2}$ and $10 \mathrm{mM}$ Tris- $\mathrm{Cl}, \mathrm{pH} 7.4$, for $5 \mathrm{~min}$ and the precipitated calcium channels were collected by filtration on Whatman GF/C filters. The samples were washed four times in ice-cold PEG solution and quantified in a scintillation counter. The correction factor for loss of bound ligand in the filter-binding assay was 0.7 (Westenbroek et al., 1992).

${ }^{125} \mathrm{I}-\omega$-CTx GVIA binding was measured by incubation of $300 \mu \mathrm{l}$ of WGA extract containing $0.05 \%$ BSA with $3 \mu$ labeled toxin $(0.3 \mu \mathrm{Ci}$ at $2200 \mathrm{Ci} / \mathrm{mmol}$ ) at a final concentration of $0.45 \mathrm{nM}$ for $20 \mathrm{~min}$ on ice. Samples were immunoprecipitated with $10-20 \mu \mathrm{g}$ of the peptide affinity-purified antibodies anti-CNE1, anti-CNE2, anti-CNB2, or control rabbit IgG as described above, and after washing the matrix was transferred to vials for scintillation counting. Total ${ }^{125} \mathrm{I}-\omega$-CTx GVIA binding was determined using $20 \mu \mathrm{l}$ of the labeled WGA extract in the filterbinding assay described above for ${ }^{3} \mathrm{H}-\mathrm{PN} 200-110$.

${ }^{125} \mathrm{I}-\omega$-CTx MVIIC binding was determined by addition of 200,000 $\mathrm{cpm}$ of labeled toxin $(3000 \mathrm{cpm} / \mathrm{fmol})$ to $50 \mu \mathrm{l}$ of WGA extract with $0.5 \%$ BSA to yield a final concentration of $1.3 \mathrm{nM} \omega$-CTx MVIIC and incubation at $4^{\circ} \mathrm{C}$ for $30 \mathrm{~min}$ on a tilting mixer. This mixture was added to $20 \mu \mathrm{g}$ of peptide affinity-purified anti-CNE2, anti-CNC1, anti-CNA3, or control rabbit IgG coupled to $2 \mathrm{mg}$ of protein $\Lambda$ Sepharose, and incubated for $5 \mathrm{hr}$ at $4^{\circ} \mathrm{C}$ in a tilting mixer. Samples were washed quick- ly three times in $10 \mathrm{~mm}$ Tris- $\mathrm{Cl}, \mathrm{pH} 7.4,100 \mathrm{~mm} \mathrm{NaCl}, 0.1 \%$ digitonin, $0.5 \% \mathrm{BSA}$, and the pellets transferred to vials for scintillation counting.

Immunocytochemistry. Adult Sprague-Dawley rats were anesthetized with sodium pentabarbitol and perfused intracardially with a solution of $4 \%$ paraformaldehyde in $\mathrm{PB}(0.1 \mathrm{M}$ sodium phosphate, $\mathrm{pH} 7.4)$ containing $0.34 \%$ L-lysine and $0.05 \%$ sodium $m$-periodate (McLean and Nakane, 1974). The brains were immediately removed from the cranium and cryo-protected by immersion in successive solutions of $10 \%, 20 \%$, and $30 \%(\mathrm{w} / \mathrm{v})$ sucrose in $\mathrm{PB}$ at $4^{\circ} \mathrm{C}$ over $72 \mathrm{hr}$. Coronal and sagittal sections $(40 \mu \mathrm{m})$ were cut on a sliding microtome and placed in $0.1 \mathrm{M}$ PB for 16-24 hr

Free-floating sections were processed for immunofluorescence using the ABC method (Hsu et al., 1981). Tissue sections were rinsed in TB (100 mM Tris-HCl, $\mathrm{pH} \mathrm{7.4)} \mathrm{for} 10 \mathrm{~min}$ and then TBS (100 mM Tris$\mathrm{HCl}, \mathrm{pH} 7.4,150 \mathrm{~mm} \mathrm{NaCl}$ ) for $10 \mathrm{~min}$. The tissue was then blocked in $1 \%$ avidin in TBS for $30 \mathrm{~min}$, rinsed in TBS for 10 min followed by $1 \%$ biotin for $30 \mathrm{~min}$, and rinsed with TBS for $30 \mathrm{~min}$. Sections were incubated in affinity-purified anti-CNE1 or anti-CNE2 antibody (diluted 1:15) for $1 \mathrm{hr}$ at room temperature followed by $36 \mathrm{hr}$ at $4^{\circ} \mathrm{C}$. All antisera were diluted in TBS containing $1 \%$ normal goat serum and $0.1 \%$ Triton $X-100$. The tissue sections were processed as follows at room temperature, except when otherwise stated: rinsed for $1 \mathrm{hr}$ in TBS containing $0.1 \%$ Triton X-100, incubated in biotinylated anti-rabbit IgG diluted 1:300 for $1 \mathrm{hr}$ at $37^{\circ} \mathrm{C}$, rinsed for $1 \mathrm{hr}$ in TBS containing $0.1 \%$ Triton X-100, incubated in avidin D fluorescein, diluted $1: 300$ for $2 \mathrm{hr}$ at $37^{\circ} \mathrm{C}$, rinsed in TBS for $15 \mathrm{~min}$, and finally rinsed in $\mathrm{TB}$ for $30 \mathrm{~min}$ before being mounted on gelatin-coated slides and coverslipped using Vectashield. The tissue was viewed using a Bio-Rad $600 \mathrm{MRC}$ confocal microscope.

To determine the level of nonspecific staining, control sections were incubated either without primary antibody or by blocking the primary antibody by preincubation for $6-8 \mathrm{hr}$ with the corresponding peptide $(20 \mu \mathrm{M})$ or with a different $\alpha_{1 E}$ peptide $(20 \mu \mathrm{M})$ prior to incubation of the antibody with the tissue.

\section{Results}

\section{Identification of the $\alpha_{I E}$ polypeptide from rat brain}

The anti-CNE1 and anti-CNE2 antibodies were raised against unique peptides from the putative cytoplasmic loop between domains II and III of $\alpha_{1 \mathrm{E}}$. Affinity-purified anti-CNEI and antiCNE2 each immunoprecipitated polypeptides with identical molecular mass and biochemical properties and therefore were used interchangeably in our experiments (data not shown). In order to determine the size and heterogeneity of $\alpha_{1 \mathrm{E}}$ polypeptides from rat brain, anti-CNE antibodies were used to immunopurify the $\alpha_{1 E}$ polypeptides from a detergent-solubilized membrane preparation by immunoblotting with anti-CNE2 (Fig. 1). Anti-CNE2 recognized a single broad protein band, which extended from $245 \mathrm{kDa}$ to $255 \mathrm{kDa}$, when either anti-CNE1 (Fig. 1A, lane 1) or anti-CNE2 (Fig. 1A, lane 2) was used as the immunoprecipitating antibody. No protein band was observed when rabbit IgG was used as the immunoprecipitating antibody (Fig. 1A, lane 3 ). The observed molecular mass is consistent with that predicted from the rat $\alpha_{1 \mathrm{E}}$ cDNA sequence (252 kDa, Soong et al., 1993). The width of this protein band suggests the presence of multiple $\alpha_{1 \mathrm{E}}$ polypeptides differing by less than $10 \mathrm{kDa}$ in apparent molecular mass. This is unlikely to be the result of partial proteolytic degradation because the entire purification procedure was carried out at $4^{\circ} \mathrm{C}$ or on ice with a high concentration of six protease inhibitors and a $1 \mathrm{hr}$ preincubation of the extract at $37^{\circ} \mathrm{C}$ in the absence of protease inhibitors revealed no change in the appearance and distribution of the $245-255 \mathrm{kDa}$ band (data not shown). As a further test of the specificity of the anti$\mathrm{CNE}$ antibodies, immunoblotting was performed in the absence and presence of $10 \mu \mathrm{M}$ competing peptide (Fig. 1B). The 245$255 \mathrm{kDa}$ polypeptide band was detected on immunoblots probed with anti-CNF2 antibody in the absence (Fig 1 $B$, lane 1) but not in the presence (Fig $1 B$, lane 2 ) of CNE2 peptide. In contrast, 
A

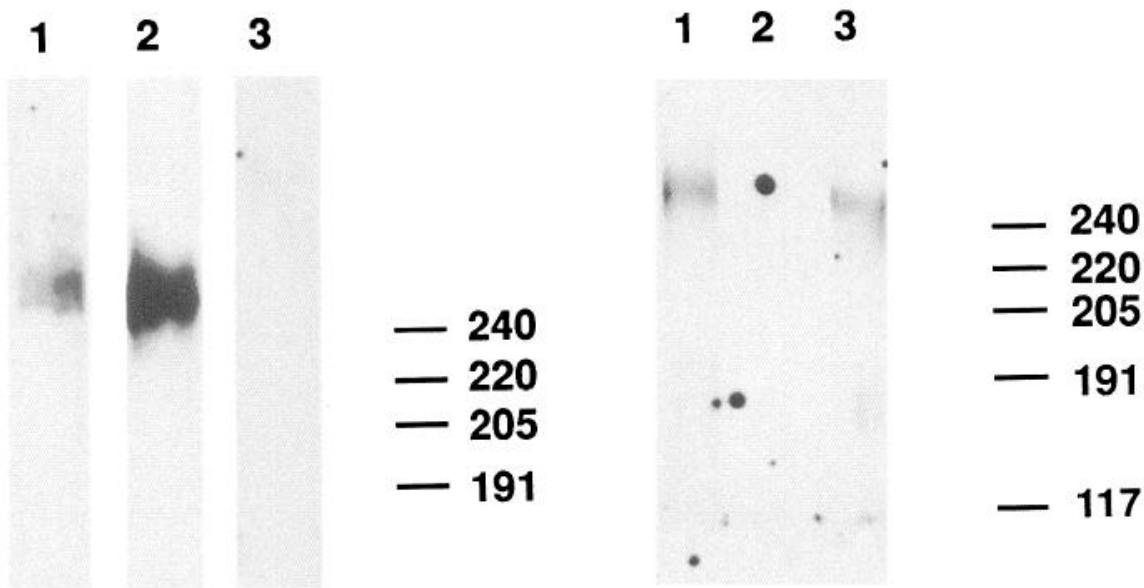

Figure 1. Immunoblotting with anti-CNE2 detects a broad protein band of 245-255 kDa. A, Calcium channels were enriched from solubilized brain membranes by WGA affinity chromatography and immunoprecipitated with anti-CNE1 (lane I), anti-CNE2 (lane 2), or control rabbit IgG (lane 3). Samples were separated by SDS-polyacrylamide gel electrophoresis, immunoblotted with affinity-purified anti-CNE2, and detected with the ECL method as described in the Materials and Methods. The molecular weight indicators are $\alpha$ and $\beta$-spectrin (220 and $240 \mathrm{kDa}$ ), myosin heavy chain $(205 \mathrm{kDa})$, and $\alpha_{2}$-macroglobulin covalently linked to Coomassie brilliant blue (191 kDa), and are shown to the right of the gel together with their respective molecular masses in kilodaltons. $B$, Channels were immunoprecipitated with anti-CNE2 as described above, and immunoblotted with anti-CNE2 in the absence (lane l) or presence (lane 2) of $10 \mu \mathrm{M}$ competing CNE2 peptide or with $10 \mu \mathrm{M}$ of a nonspecific CNE1 control peptide (lane 3). Molecular mass standards are indicated by the gel as in $A$ including $\beta$-galactosidase covalently linked to Coomassie brilliant blue $(117 \mathrm{kDa})$

incubation of the same blot with anti-CNE2 antibody in the presence of CNE1 peptide (Fig. 1B, lane 3) did not block recognition of the $245-255 \mathrm{kDa}$ polypeptide, providing further evidence for specificity of the CNE2 peptide block. Together, these immunoblotting data identify an $\alpha_{\mathrm{IE}}$ polypeptide from rat brain in the $245-255 \mathrm{kDa}$ size range. The broad protein band may indicate the presence of multiple $\alpha_{1 E}$ polypeptides of similar size.

\section{Phosphorylation of the $\alpha_{I E}$ polypeptide}

Voltage-gated calcium channel $\alpha_{1}$ subunits contain consensus sites for phosphorylation by multiple second-messenger-activated protein kinases within their cytoplasmic domains, and direct phosphorylation of $\alpha_{1}$ subunits has been shown previously to be an important modulatory pathway for voltage-gated calcium channels (Trautwein and Hescheler, 1990; Armstrong et al., 1991; Sculptoreanu et al., 1993). In vitro phosphorylation of $\alpha_{1 \mathrm{E}}$ by purified protein kinases is a first step toward functional studies of channel phosphorylation, and also serves as a method for radiolabeling $\alpha_{\mathrm{IE}}$ subunits for immunochemical studies. AntiCNE2 was used to immunoprecipitate and concentrate $\alpha_{I E}$ subunit polypeptides from the WGA fraction onto a protein ASepharose affinity matrix, and the $\alpha_{\mathrm{IE}}$ subunits were then incubated with purified PKA and $\gamma^{32}{ }^{32}$-ATP, resolved by SDSPAGE, and detected by autoradiography. The anti-CNE2-immunopurified $\alpha_{1 \mathrm{E}}$ subunit polypeptide was substantially phosphorylated by PKA, while no phosphoprotein band was detected with control rabbit $\operatorname{IgG}$ (Fig. 2A, lanes 1 and 2).

$\alpha_{1}$ subunits of voltage-gated calcium channels interact with auxiliary subunits and also may associate with other plasma membrane, vesicular, or cytoskeletal proteins. Thus, the antiCNE2 immunoprecipitations performed under native conditions may isolate PKA substrates which are associated with $\alpha_{1 \mathrm{IE}}$ subunit and have a similar size. In order to rule out this possibility, a double immunoprecipitation procedure was used in which
PKA-phosphorylated anti-CNE2 immunoprecipitates were denatured by heating the samples in SDS and DTT to dissociate proteins associated with $\alpha_{1 \mathrm{E}}$, diluted into Triton X-100, and reprecipitated with a second antibody. When $\alpha_{\mathrm{IE}}$ polypeptides were doubly immunoprecipitated with anti-CNE2, there was no change in the apparent molecular mass, distribution, or intensity of the 245-255 kDa phosphoprotein band (Fig. 2A, lane 3), indicating that the PKA substrate is $\alpha_{1 \mathrm{E}}$ itself rather than an associated polypeptide. A rabbit IgG double precipitation did not yield any PKA-phosphorylated polypeptides (Fig. 2A, lane 4). To confirm the identity of the $245-255 \mathrm{kDa}$ polypeptide as a calcium channel $\alpha_{1}$ subunit, we used anti-CP15 which recognizes a peptide segment conserved in all known rat voltage-dependent calcium channels and has been shown to immunoprecipitate the $\alpha_{1 \mathrm{~S}}, \alpha_{1 \mathrm{~A}}, \alpha_{1 \mathrm{~B}}, \alpha_{1 \mathrm{C}}$, and $\alpha_{1 \mathrm{D}}$ polypeptides (Striessnig et al., 1990; Ahlijanian et al., 1991; Hell et al., 1993b, 1994; Westenbroek et al., 1993; Sakurai and Catterall, unpublished observations). This segment is accessible to anti-CP15 only after solubilization in Triton X-100 or other detergents which remove the $\alpha_{2} \delta$ subunit. Double immunoprecipitation with anti-CNE2 and anti-CP15 reveals the same 245-255 kDa phosphoprotein band, confirming its identity as a calcium channel $\alpha_{1}$ subunit (Fig. 2A, lane 5). In order to examine the peptide specificity of the antiCNE2 antibody in the immunoprecipitation and phosphorylation procedures, immunoprecipitations were done in the absence or presence of competing peptides. Incubation of the immunoprecipitation reaction with $2 \mu \mathrm{M}$ CNE2 peptide effectively blocked recognition of the PKA-phosphorylated $\alpha_{I E}$ subunit (Fig. $2 B$ ).

The ability of the $\alpha_{\text {IE }}$ subunit to act as a substrate for other second-messenger-activated protein kinases was assessed by phosphorylating the anti-CNE2-immunoprecipitated $\alpha_{1 \mathrm{E}}$ subunit with each protein kinase followed by denaturation and reprecipitation with anti-CP15 to ensure that the substrate was the $\alpha_{1 \mathrm{E}}$ polypeptide. In addition to PKA (Fig. $2 C$, lane 1), the $\alpha_{1 \mathrm{IE}}$ sub- 
A

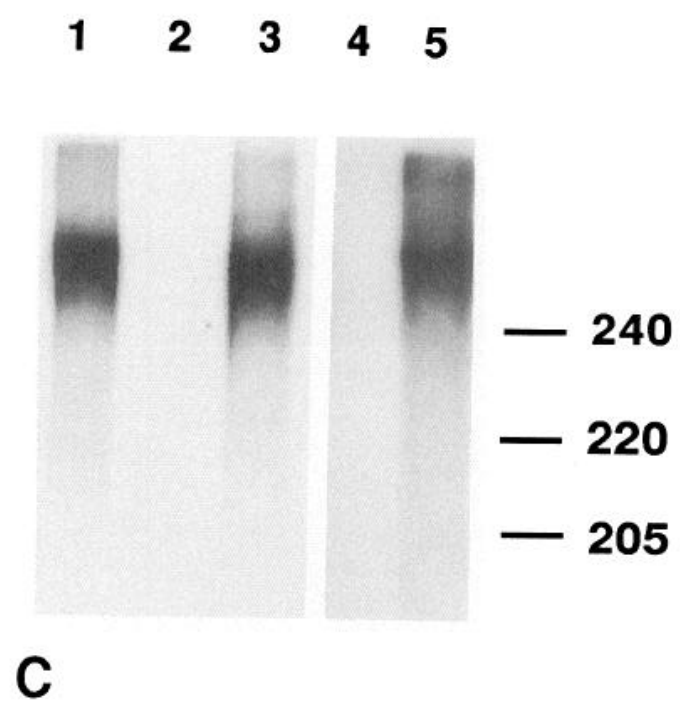

12

34

56

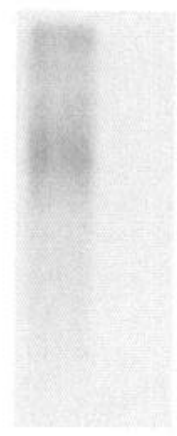

PKG
B

\section{2}

\section{8}

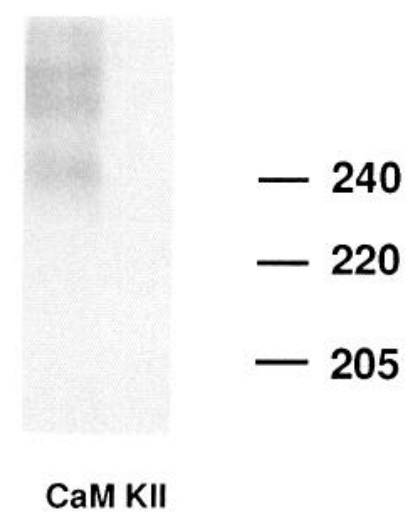

Figure 2. Phosphorylation of the $\alpha_{1 \mathrm{E}}$ subunit by protein kinases. $A, \alpha_{1 E}$ subunits were immunoprecipitated with anti-CNE2 (lane 1) or control rabbit IgG (lane 2), phosphorylated with PKA, and analyzed by SDS-polyacrylamide gel electrophoresis. Double immunoprecipitations were performed with anti-CNE2 (lane 3) or control rabbit IgG (lane 4) as both first and second antibody, or anti-CNE2 followed by anti-CP15 (lane 5). Channels were phosphorylated between the first and second immunoprecipitation steps. $B$, Immunoprecipitation with anti-CNE2 was done in the absence (lane 1) or presence (lane 2) of $2 \mu \mathrm{M}$ competing CNE2 peptide and followed by PKA phosphorylation. $C$, Channels were immunoprecipitated with either anti$\mathrm{CNE} 2$ (lanes $1,3,5,7$ ) or control rabbit IgG (lanes $2,4,6,8$ ), phosphorylated with PKA (lanes 1, 2), PKC (lanes 3, 4), PKG (lanes 5, 6), or Cam KII (lanes 7,8 ), and then reimmunoprecipitated with anti-CP15. Molecular mass markers are indicated as in Figure 1 . unit is a substrate for phosphorylation by $\mathrm{PKC}, \mathrm{PKG}$, and CaM KII (Fig. 2C, lanes 3, 5, and 7). Nonimmune rabbit IgG was ineffective in precipitating $\alpha_{1 \mathrm{E}}$ phosphorylated by the different kinases (Fig. 2C, lanes 2, 4, 6, and 8). The distinct high molecular mass bands observed for CaM KII are likely to be nonspecific as they were observed in control rabbit IgG lanes in longer exposures (not shown). The fainter high molecular weight bands and diffuse radioactivity appearing in the other lanes probably represent incompletely denatured aggregates of $\alpha_{1 \mathrm{E}}$ with other polypeptides. These results demonstrate that the $\alpha_{1 \mathrm{E}}$ is an in vitro substrate for several second-messenger-activated protein kinases, and suggest the possibility that phosphorylation of $\alpha_{1 \mathrm{E}}$ may influence its functional properties (e.g., Stea et al., 1994b).

\section{Binding of calcium channel blockers to $\alpha_{I E}$}

Selective block of voltage-gated calcium currents by various natural peptides and synthetic compounds is used as a criterion for distinguishing the different calcium current types in neurons, for characterizing cloned calcium channel $\alpha_{1}$ subunits in expression systems, and for radiolabeling $\alpha_{1}$ subunits during biochemical purification. Since previous work has shown that the ligandbinding profile of a purified $\alpha_{1}$ subunit can be used to predict the identity of the calcium channel type (Dubel et al., 1992), we have tested the binding to $\alpha_{1 \mathrm{E}}$ of radiolabeled ligands known to selectively block various calcium currents in neurons. ${ }^{3} \mathrm{H}$-Isradipine $\left({ }^{3} \mathrm{H}-\mathrm{PN} 200-110\right)$ is a dihydropyridine compound which specifically binds to $\alpha_{1 \mathrm{C}^{-}}$and $\alpha_{1 \mathrm{D}}$-containing L-type calcium channels. At a concentration of $0.57 \mathrm{nM}{ }^{3} \mathrm{H}$-isradipine, anti$\mathrm{CNC1}$, an $\alpha_{1 \mathrm{c}}$-specific site-directed antipeptide antibody (Hell et al., 1993a), immunoprecipitated $72 \%$ of total ${ }^{3} \mathrm{H}$-isradipine binding sites while anti-CNE2 immunoprecipitated less than $2 \%$, a value similar to that obtained with control rabbit IgG (Fig. $3 A$ ). Anti-CNB1, an $\alpha_{1 B}$-specific site-directed antipeptide antibody (Westenbroek et al., 1992), immunoprecipitated over $90 \%$ of total ${ }^{125} \mathrm{I}-\omega$-CTx GVIA binding sites in the WGA fraction detected by incubation with $0.45 \mathrm{nM}$ of labeled toxin, but anti-CNE2 and control rabbit IgG recognized less than $5 \%$ of total ${ }^{125} \mathrm{I}-\omega-\mathrm{CTx}$ GVIA binding (Fig. 3B). $\omega$-CTx MVIIC inhibits calcium channels containing $\alpha_{1 \mathrm{~A}}$ subunits. Addition of $1.3 \mathrm{nM}{ }^{125} \mathrm{I}-\omega-\mathrm{CTx}$ MVIIC to the WGA fraction followed by immunoprecipitation with anti-CNA3, an $\alpha_{1 \mathrm{~A}}$-specific site-directed antipeptide antibody (Sakurai and Catterall, unpublished observations), revealed the immunoprecipitation of specific ${ }^{125} \mathrm{I}-\omega$-CTx MVIIC binding sites. In contrast, anti-CNE2 and anti-CNC1 did not immuno- 

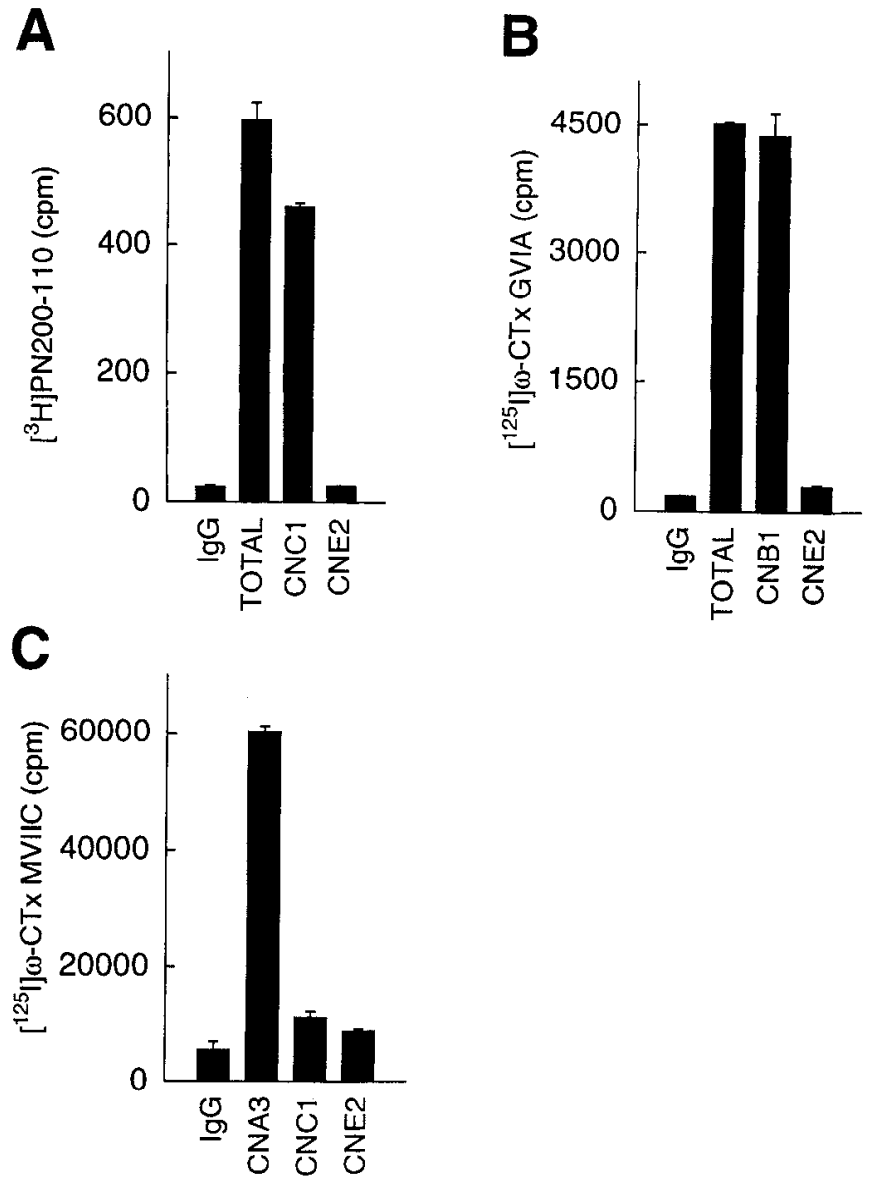

Figure 3. Radioligand binding profile of $\alpha_{1 \mathrm{E}}$. A, Brain membranes were labeled with ${ }^{3} \mathrm{H}$-isradipine, solubilized with digitonin, and calcium channels were enriched by WGA chromatography. Channels were immunoprecipitated with rabbit IgG, anti-CNC1, or anti-CNE2 and ${ }^{3} \mathrm{H}$ quantitated by scintillation counting. Total bound ${ }^{3} \mathrm{H}$-isradipine was determined by filter-binding assay and corrected for filter efficiency as described in Materials and Methods. $B$, Calcium channels enriched by WGA chromatography were labeled with ${ }^{125} \mathrm{I}-\omega-\mathrm{CTx}$ GVIA and immunoprecipitated with control rabbit IgG, anti-CNB1, or anti-CNE2 and bound ${ }^{125} \mathrm{I}$ was quantitated by scintillation counting. Total bound ${ }^{125} \mathrm{I}-\omega-$ CTx GVIA was determined by filter-binding assay and corrected for filter efficiency. $C$, Calcium channels enriched by WGA chromatography were labeled with ${ }^{125} \mathrm{I}-\omega$-CTx MVIIC and immunoprecipitated with control rabbit IgG, anti-CNA3, anti-CNCl, or anti-CNE2, and bound ${ }^{125}$ I was quantitated by scintillation counting. In $A$ through $C$, the values are presented as the mean \pm SEM for $n=3(A, B)$ or $n=4(C)$ experiments.

precipitate significantly more than the nonspecific binding of rabbit IgG (Fig. $3 C$ ). Our results are consistent with previous studies showing that $\alpha_{1 E}$ expressed in Xenopus oocytes or mammalian cells is not inhibited by dihydropyridines, $\omega$-CTx GVIA, or $\omega$-CTX-MVIIC (Soong et al., 1993; Williams et al., 1994). Evidently, these agents neither bind to nor inhibit class $\mathrm{E}$ calcium channels.

\section{Regional and subcellular distribution of class $E$ calcium channels}

Both anti-CNE1 and anti-CNE2 antibodies were used in localization studies and gave similar patterns of staining. Throughout the rostral-caudal extent of the rat brain, there is significant labeling of the majority of neurons by the CNE antibodies. Both projection neurons and interneurons are immunoreactive for the $\alpha_{1 E}$ subunits recognized by the anti-CNE1 or anti-CNE2 antibodies. The most prominent staining in rostral areas was observed in deep ventral structures such as the caudate-putamen, globus pallidus, thalamus, hypothalamus, and amygdala. The density of labeling is highest in the cell soma in most brain regions, but substantial labeling of dendrites of specific neurons was also observed. To illustrate these points, selected regions and nuclei are described in greater detail bclow.

In all regions of the dorsal cortex, neurons throughout layers 1-6 are immunoreactive for $\alpha_{1 \mathrm{E}}$ with the most prominent staining observed in layers 3-5 (Fig. 4A). The highest concentration of $\alpha_{1 \mathrm{E}}$ immunoreactivity is in the cell bodies. Similar to $\alpha_{1 \mathrm{C}}$ and $\alpha_{1 \mathrm{D}}$ (Hell et al., 1993a), $\alpha_{1 \mathrm{E}}$ staining extends only into the proximal portion of the dendrites of cortical neurons and is faint compared with cell body staining.

In the olfactory bulb, there is extensive labeling of class $\mathrm{E}$ calcium channels throughout most layers. The periglomerular cells which surround the glomeruli of the bulb are immunoreactive for $\alpha_{1 \mathrm{E}}$. In addition, tufted cells located in the external plexiform layer, the large mitral cells in the mitral cell layer, and the numerous small interneurons, the granule cells, located in the internal granular layer are all immunoreactive for the $\alpha_{1}$ subunit of rat brain class $\mathrm{E}$ calcium channels (Fig. $4 B$ ). There is also extensive labeling of dendrites in the external plexiform layer, where dendrodendritic synapses on mitral cell dendrites are located, and moderate labeling of dendrites in the internal plexiform layer (Fig. 4B).

In the caudate-putamen there is dense labeling of cell bodies, especially at locations where dendrites originate (Fig. $4 C$ ). This staining is most prevalent in medium-sized neurons $(10-20 \mu \mathrm{m}$ in diameter) which make up greater than $95 \%$ of the neurons located in the caudate-putamen. The specificity of staining is indicated by block of staining by the anti-CNE1 antibody using the CNE1 peptide (Fig. 4D) and block of staining by the antiCNE2 antibody using the CNE2 peptide (Fig. $4 E$ ).

Neurons located in the globus pallidus are also immunoreactive for class E calcium channels. At lower magnification, immunoreactive cell bodies appear densely stained compared to the surrounding neuropil and myelinated fiber bundles (Fig. 5A). At higher magnification (Fig. $5 B$ ), both the cell bodies and the large dendritic branches of the large fusiform or triangular neurons of this region are immunoreactive for $\alpha_{1 \mathrm{E}}$, as are their dendritic branches. The surrounding neuropil is also immunoreactive for class E calcium channels. The majority of this staining appears to be in dendritic processes, although a portion of it has a punctate appearance which may suggest localization within synaptic terminals.

A similar pattern of cell body, dendritic, and neuropil staining was observed throughout the thalamus (Fig. $5 C$ ). Preincubation of the anti-CNE2 antibody with the CNE1 peptide did not change the pattern of staining as compared to incubation with anti-CNE2 antibody alone (Fig. 5D). A similar result was obtained when the anti-CNE1 antibody was preincubated with the CNE2 peptide. This control plus the peptide blocks shown in Figure $4, D$ and $E$, demonstrates that the anti-CNE1 and antiCNE2 antibodies each recognize a specific sequence within the $\alpha_{1 \mathrm{E}}$ subunit.

In the amygdala, there is extensive staining of class $E$ calcium channels in the cell bodies and dendrites of neurons. This pattern of staining was especially prominent in the anterior amygdala (Fig. 5E,F), and was also observed in the other major subdivisions of the amygdala. At lower magnifications there is extensive 

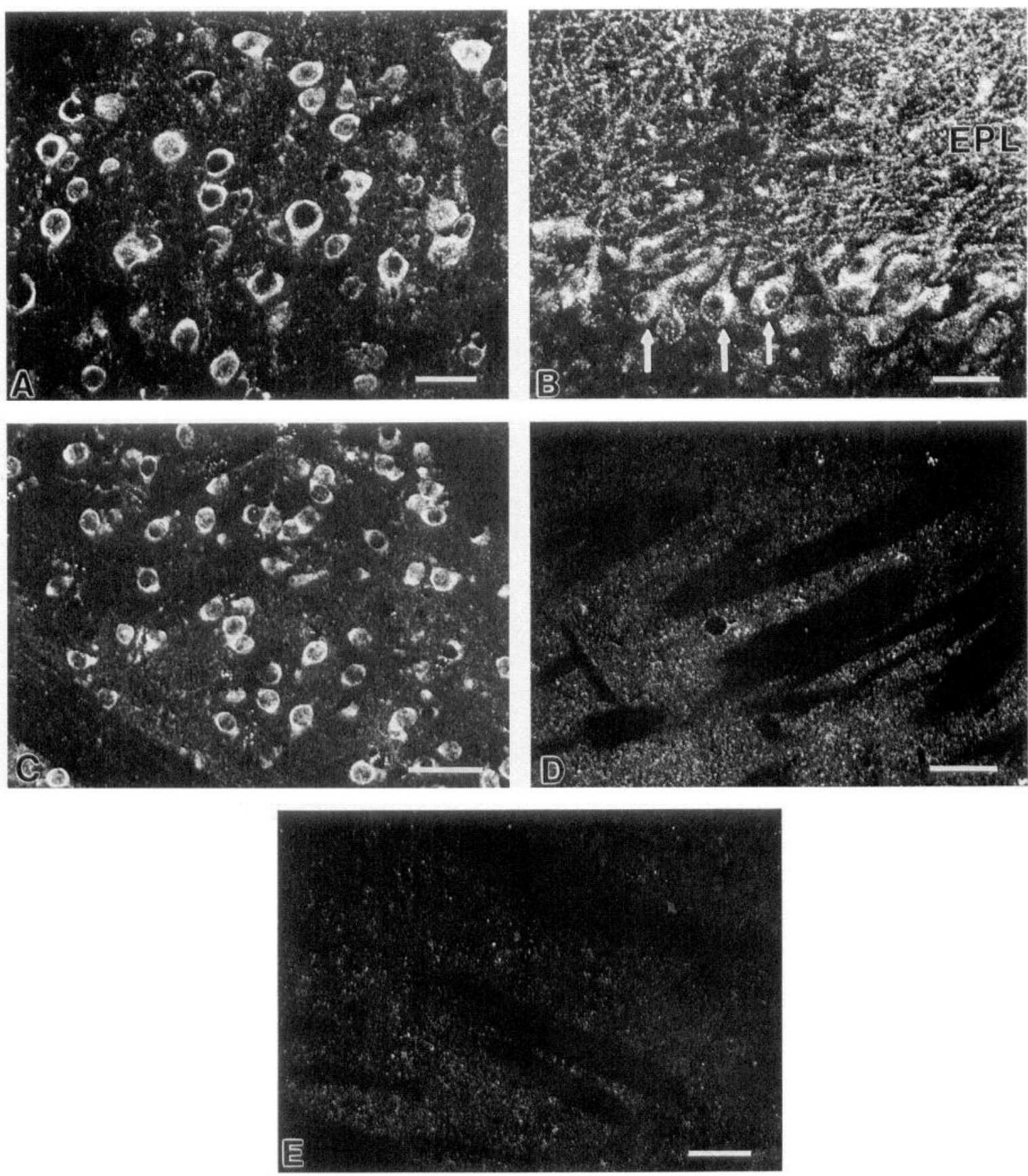

Figure 4. Localization of class E calcium channels in forebrain regions. Sagittal sections of adult rat brain were stained with affinity purified antiCNE1 or anti-CNE2 antibodies using the immunofluorescence technique described in Materials and Methods. A, Section taken from layers IV and $\mathrm{V}$ of the dorsal cortex to demonstrate class $\mathrm{E}$ staining in cell bodies. $B$, Section taken from the olfactory bulb illustrating dense class $\mathrm{E}$ calcium channel staining in the mitral cells (arrows) and in their dendrites located in the external plexiform layer $(E P L)$. $C$, Class $\mathrm{E}$ calcium channel staining in the cell body of neurons in the caudate-putamen. Control sections from caudate nucleus in which anti-CNE1 antibody is preincubated with the CNE1 peptide $(D)$ or the anti-CNE2 antibody is preincubated with the CNE2 peptide $(E)$. Scale bars, $50 \mu \mathrm{m}$.

staining of cell bodies, dendrites and the surrounding neuropil. Regions of myelinated tracts were not stained. At higher magnifications, punctate staining is observed in the neuropil and along dendritic branches.

In the hippocampal formation, we also observed a wide distribution of neurons which are immunoreactive for class $\mathrm{E}$ calcium channels recognized by the anti-CNE1 and anti-CNE2 antibodies. Cell bodies of pyramidal neurons in the CA1 (Fig. 6A) and in the CA2/CA3 regions (Fig. $6 B$ ) and granule cells in the dentate gyrus are stained with the CNE antibodies. Some interneurons in the strata oriens, radiatum, and lacunosum moleculare of the hippocampus and interneurons in the molecular layer of the dentate gyrus are also immunoreactive for $\alpha_{1 \mathrm{E}}$. In all regions, there is dense immunoreactivity in neuronal cell bodies. In the CA1 region there is an apparent lack of staining in the apical and basal dendrites of the pyramidal neurons while in the CA2/ CA3 region there is faint staining of the proximal portion of the apical dendrites. This is in contrast to the significant staining of 

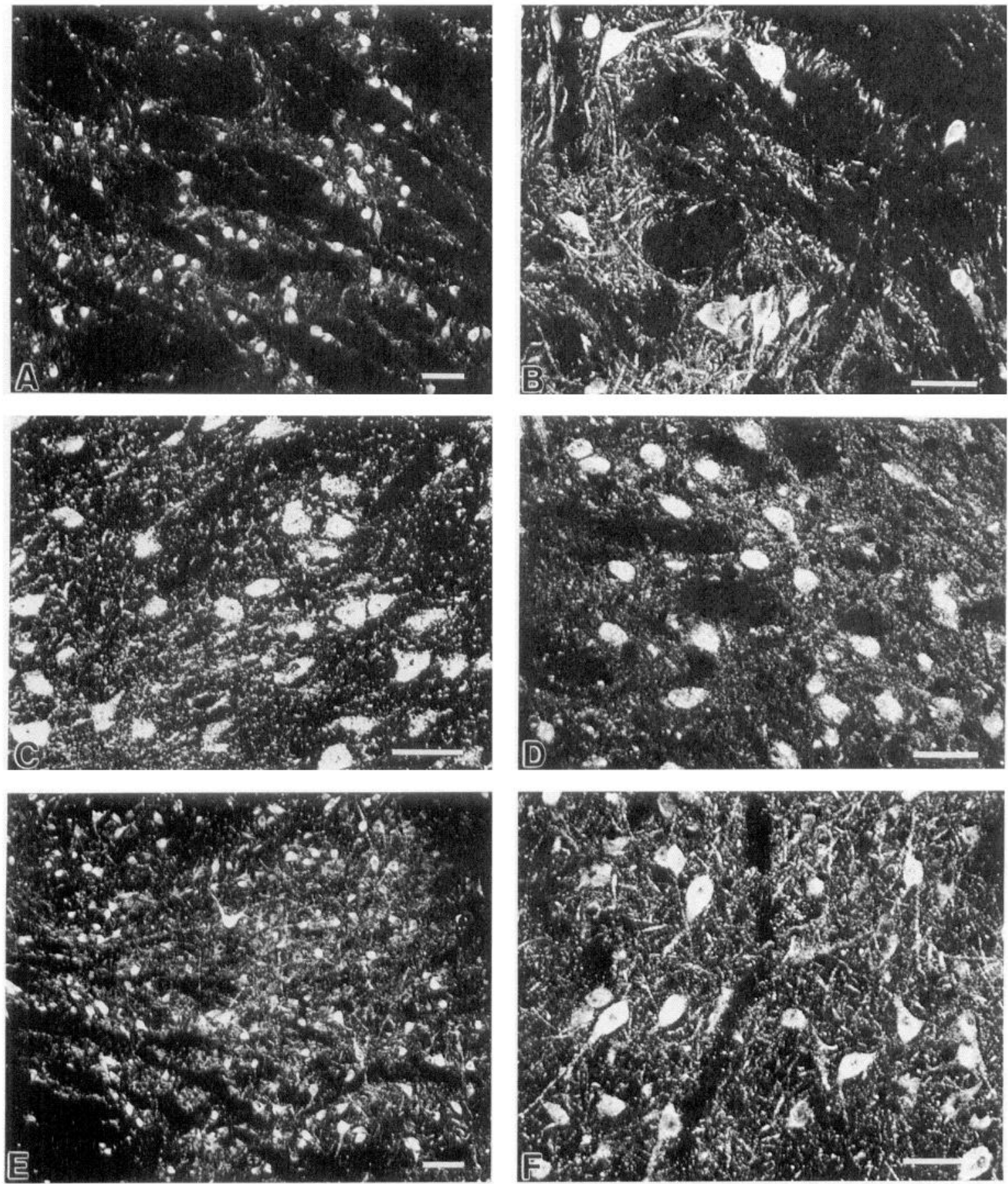

Figure 5. Distribution of class E calcium channels in the globus pallidus, thalamus, and anterior amygdala. Sagittal sections of adult brain with class $\mathrm{E}$ antibodies using the immunofluorescence technique described in the Materials and Methods. Low magnification $(A)$ of the globus pallidus and a higher magnification $(B)$ to illustrate staining of both cell bodies and dendrites of neurons located in this region. $C$, Section of class $\mathrm{E}$ calcium channel staining in the thalamus. $D$, Control section in which class $\mathrm{E}$ antibody is preincubated with CNE2 peptide. Low $(E)$ and high $(F)$ magnifications of the anterior amygdala region to demonstrate staining in both cell bodies and dendrites. Scale bars: $A$ and $E, 200 \mu \mathrm{m} ; B-D$ and $F, 100 \mu \mathrm{m}$.

the proximal portion of the apical dendrites with antibodies against $\alpha_{1 \mathrm{C}}$ and $\alpha_{1 \mathrm{D}}$ (Ahlijanian et al., 1990; Westenbroek, 1990; Hell et al., 1993a) and the dense staining observed along the length of the apical dendrites using antibodies against $\alpha_{1 \mathrm{~B}}$ (Westenbroek et al., 1992). There was also occasional staining of the dendritic processes of interneurons located in the dentate gyrus.

Class E calcium channels are also present in other nuclei throughout the rat brain. Figure 7 illustrates a few of these regions which include the subthalamic nucleus, the lateral hypothalamus, the facial nucleus, and the deep cerebellar nuclei. In all regions, there is extensive staining of the cell bodies of neurons (Fig. $7 A-D$ ) with variable staining of dendrites. For example, there is relatively little staining of dendrites in the subthalamic nucleus while dendritic staining is more prevalent in 

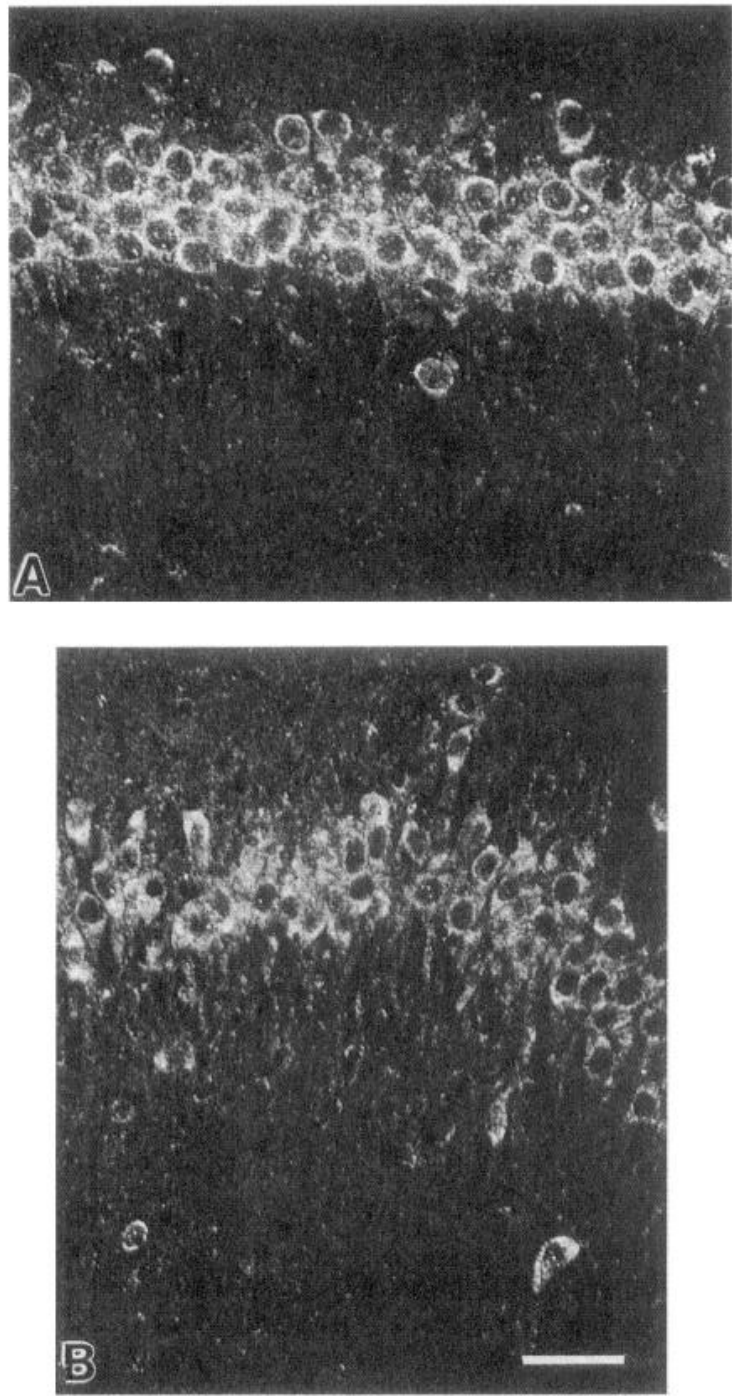

Figure 6. Distribution of class E calcium channels in the hippocampus. Sagittal sections of adult brain stained with class $\mathrm{E}$ calcium channel antibodies as described in the Materials and Methods. $A$, Immunoreactive cell bodies of CA1 pyramidal neurons. $B$, Labeled cell bodies of pyramidal neurons in the $\mathrm{CA} 2 / \mathrm{CA} 3$ region of the hippocampus. Scale bar, $100 \mu \mathrm{m}$.

the facial nucleus. This variability of dendritic staining is observed along the length of the brainstem and appears to be nucleus dependent.

In the cerebellum, the most intense staining with the CNE antibodies is observed in the cell bodies of the principal projection neurons, the Purkinje cells. Unlike the apparent absence of staining in the dendrites of projection neurons in the dorsal cortex and the hippocampus, there is $\alpha_{1 \mathrm{E}}$ staining in the smaller dendritic branches of the cerebellar Purkinje neurons (Fig. $8 A, B)$. However, there is a striking absence of staining in the main dendritic trunks (compare Westenbroek et al., 1995, for $\alpha_{1 \mathrm{~A}}$ ). There is relatively weak but consistent staining throughout the granular layer of the cerebellum (Fig. $8 A$ ) with occasionally strong staining in randomly located granule cells. Due to the dense staining of the small branches of dendrites in the molecular layer it is difficult to determine whether the interneurons located in this layer are also immunoreactive for $\alpha_{1 \mathrm{IE}}$. As in other brain regions, the immunocytochemical staining in the cerebel- lum suggests that class E calcium channels are located mainly in the cell bodies of neurons and, depending on the region and cell type, are also present in the dendrites.

\section{Discussion}

Biochemical properties of the $\alpha_{I E}$ subunit

The predicted molecular size of $\alpha_{1 \mathrm{E}}$ from the cloned cDNA is $252 \mathrm{kDa}$ (Soong et al., 1993). In concordance, our immunoblotting experiments show that $\alpha_{1 \mathrm{E}}$ subunits purified from rat brain are $245-255 \mathrm{kDa}$ in size. It remains to be determined whether the broad protein band observed in these experiments may contain multiple $\alpha_{1 \mathrm{E}}$ isoforms of similar size. Multiple $\alpha_{1 \mathrm{E}}$ isoforms from rabbit, rat, mouse, and human brain, with small differences in predicted molecular mass have been described in cDNA cloning experiments (Marubio et al., 1994; Williams et al., 1994; Soong and Snutch, unpublished observations), including $\mathrm{COOH}$-terminal diversity generating two predicted size forms of $254 \mathrm{kDa}$ and $246 \mathrm{kDa}$ in the rabbit (Niidome et al., 1992). Microheterogeneity in the predicted primary structures of $\alpha_{1}$ subunits, most likely generated by alternative RNA splicing, is also reported for $\alpha_{1 \mathrm{~A}}, \alpha_{1 \mathrm{~B}}, \alpha_{1 \mathrm{C}}$, and $\alpha_{1 \mathrm{D}}$ subunits (Hui et al., 1991; Snutch et al., 1991; Starr et al., 1991; Williams et al., 1992a,b; Coppola et al., 1994; Hofmann et al., 1994). Our results with $\alpha_{1 \mathrm{E}}$ contrast with previous biochemical studies of rat brain $\alpha_{1 \mathrm{~B}}, \alpha_{1 \mathrm{C}}$, and $\alpha_{1 \mathrm{D}}$ in which two size forms of the $\alpha_{1}$ polypeptides differing by $30-50 \mathrm{kDa}$ were observed due to truncation of the COOH-terminal domain (Hell et al., 1993a,b, 1994, 1995). If $\alpha_{1 \mathrm{E}}$ isoforms with $\mathrm{COOH}$-terminal differences exist, they must be less than $10 \mathrm{kDa}(\sim 81$ amino acids).

Phosphorylation by second-messenger-activated protein kinases is a well-established pathway for modulation of the function of neuronal calcium channels by neurotransmitters and hormones (Dolphin, 1990; Swartz, 1993; Yang and Tsien, 1993; Meriney et al., 1994), but it is not known if this regulation involves direct phosphorylation of calcium channel subunits. As previously shown for $\alpha_{1 \mathrm{~B}}$ and $\alpha_{1 \mathrm{C}}, \alpha_{1 \mathrm{E}}$ subunits are substrates for phosphorylation in vitro by PKA, PKC, PKG, and CaM KII (Fig. $2 C$ ). PKA also phosphorylates the $\alpha_{1 \mathrm{E}}$ subunit in intact hippocampal neurons further supporting a possible functional role for this modification (Hell et al., 1995b). In addition, stimulation of PKC in Xenopus oocytes expressing $\alpha_{\mathrm{IE}}$ and $\beta$ subunit cDNAs causes a significant increase in the whole-cell $\mathrm{Ba}^{2+}$ current, suggesting a direct functional phosphorylation of $\alpha_{1 \mathrm{E}}$ and/ or $\beta$ subunits by PKC (Stea et al., 1994b). However, it remains to be determined whether the phosphorylation sites for PKC, PKG, and Cam KII on $\alpha_{1 \mathrm{E}}$ are substrates in vivo, and further experiments are required to evaluate the specific effects of activated protein kinases on $\alpha_{1 \mathrm{E}}$ channel function.

The ligand binding profile of $\alpha_{1 E}$ indicates that this subunit does not bind with high affinity to any of the peptide toxins or synthetic compounds used to characterize calcium currents in neurons or in heterologous systems expressing cloned $\alpha_{1}$ cDNAs. These results are in agreement with the Xenopus oocyte expression studies of the rat $\alpha_{1 \mathrm{E}}$ subunit. Soong et al. (1993) found that $\mathrm{I}_{\mathrm{Ba}}$ conducted by $\alpha_{\mathrm{IE}}$ was not significantly affected by $10 \mu \mathrm{M}$ nifedipine or $1 \mu \mathrm{M} \omega$-CTx GVIA, and only partially blocked by $200 \mathrm{nM} \omega$-Aga IVA. Later experiments indicated only a small (10-20\%) blockade by $5 \mu \mathrm{M} \omega$-CTx MVIIC (Stea and Snutch, unpublished observations). Thus, these calcium channel antagonists neither specifically bind to nor block calcium channels containing $\alpha_{1 \mathrm{E}}$, in ageement with the conclusion that it represents a novel type of calcium channel. 

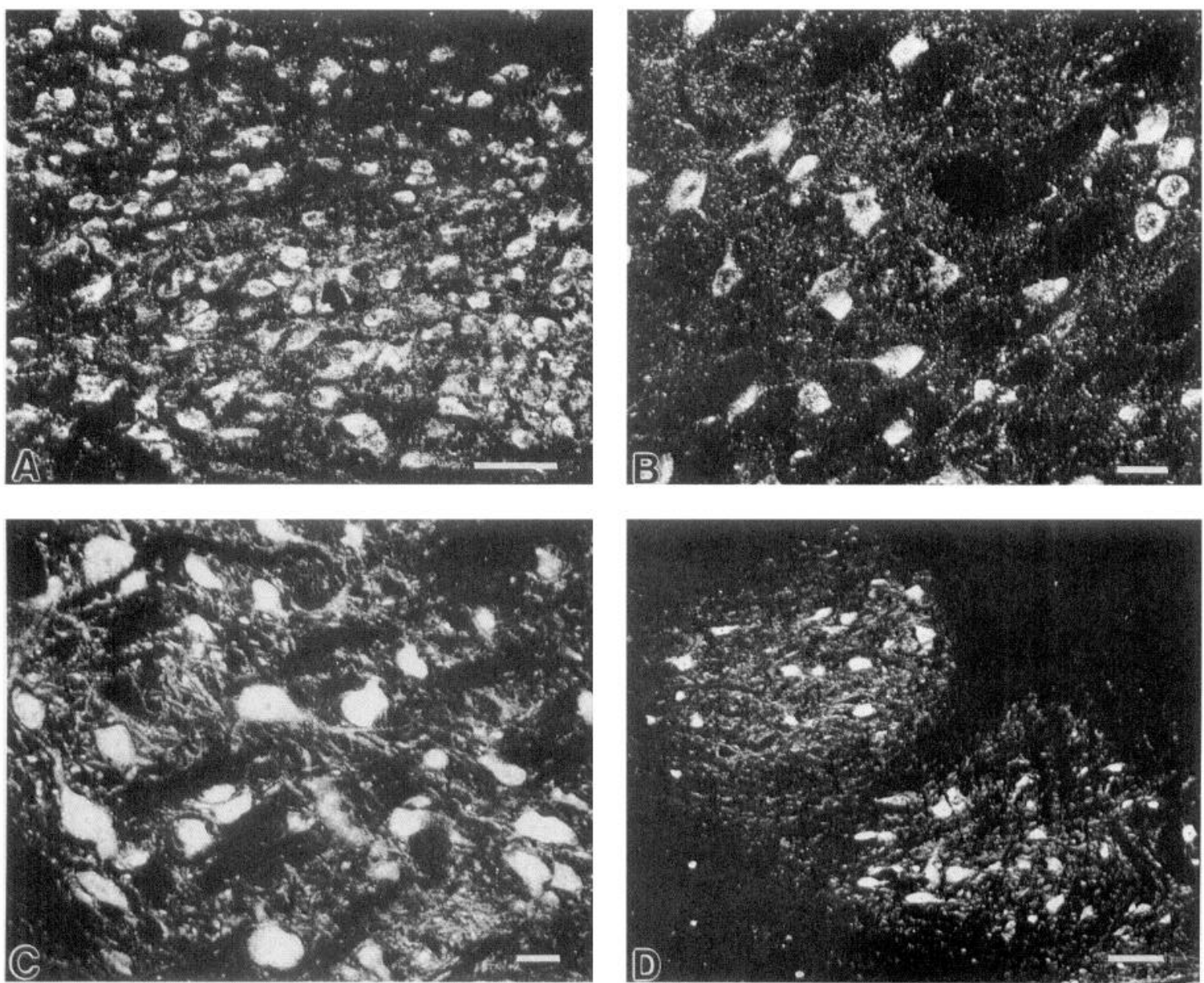

Figure 7. Staining of class E calcium channels in ventral nuclei. Sagittal sections were stained with class E calcium channel antibodies as described in Materials and Methods. A, Staining of cell bodies in subthalamic nucleus. B, Staining of dendrites and cell bodies in the lateral hypothalamus. $C$, Class $\mathrm{E}$ calcium channel staining in the cell bodies and dendrites of neurons in the facial nucleus. $D$, Class $\mathrm{E}$ immunoreactive neurons located in the deep cerebellar nuclei. Scale bars: $A-C, 50 \mu \mathrm{m} ; D, 100 \mu \mathrm{m}$.

Figure 8. Localization of class E calcium channels in the cerebellum. Sagittal sections labeled with class E calcium channels using the fluorescent method described in Materials and Methods. A, Section of cerebellum showing class $\mathrm{E}$ immunoreactivity in the molecular layer $(M)$, Purkinje cell layer $(P)$, and in the granular layer $(G)$. $B$, Staining of class E calcium channels in the fine dendrites and at dendritic branch points (arrows) of Purkinje cells $(P)$. Scale bar, $50 \mu \mathrm{m}$.
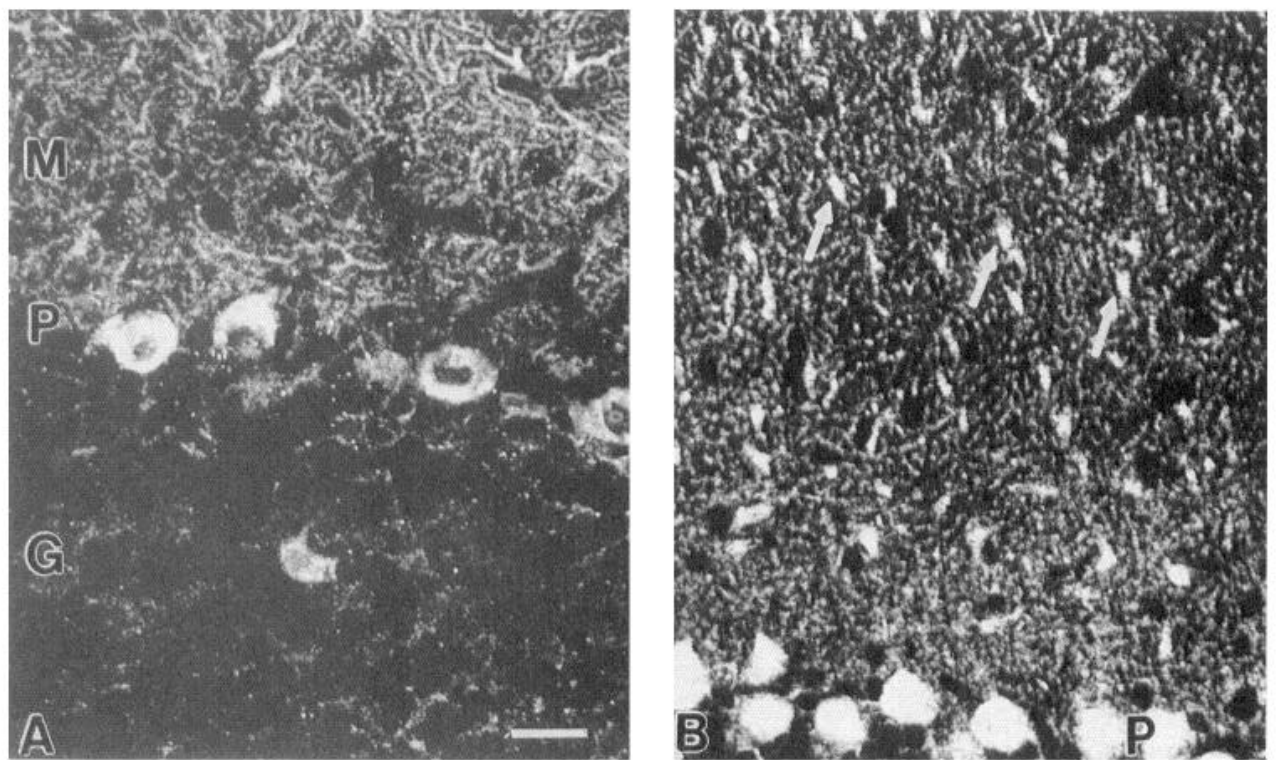


\section{Broad distribution of class $E$ calcium channels in the brain}

Overall, while there is regional variation in the pattern and relative density of anti-CNE labeling, most areas of gray matter are stained above background. This suggests that there is a broad expression of the $\alpha_{1 \mathrm{E}}$ subunit throughout the brain. In situ hybridization studies in rat and mouse showed that $\alpha_{1 \mathrm{E}}$ transcripts are widely expressed in the CNS (Soong et al., 1993; Williams et al., 1994). Consistent with these results, we find that the CNE antibodies label calcium channels in neurons throughout the brain, including the olfactory bulb, the frontal and dorsal cerebral cortex, hippocampus, midbrain, hindbrain, and cerebellum. Large amounts of rbE-II transcripts were detected in periglomerular, mitral, and granule cells of the olfactory bulb, neocortical layers II through VI, hippocampus, striatum, amygdala, hypothalamus, thalamus, and cerebellum (Soong et al., 1993). In general, our protein localization studies correspond well with these findings. However, within the thalamus, RNA expression was mainly localized to the intralaminar, parafascicular and reticular nuclei while our findings suggest that $\alpha_{1 \mathrm{E}}$ is localized throughout the entire thalamus. In addition, rbE-II transcripts were found to be relatively high in the granule cell and Purkinje cell layers of the cerebellum. Our immunocytochemical findings suggest that $\alpha_{1 \mathrm{E}}$ is prominent in Purkinje cells, but is present at a substantially lower level in the granulc cells of the granular layer. In mouse, abundant $\alpha_{1 \mathrm{E}}$ transcript levels were observed in similar regions to those investigated in the rat, although only low levels were detected in the reticular nucleus of thalamus (Williams et al., 1994). The slight differences in RNA expression between rat and mouse may be due to alternative processing of $\alpha_{1 E}$ transcripts. For example, the $\mathrm{NH}_{2}$-terminal sequences of rabbit, human, and mouse clones (Niidome et al., 1992; Williams et al., 1994) differ from that reported for the rat (Soong et al.,1993).

\section{Localization of class E calcium channels in neuronal cell bodies}

In contrast to the calcium channels containing $\alpha_{1 \mathrm{~A}}, \alpha_{1 \mathrm{~B}}, \alpha_{1 \mathrm{C}}$, or $\alpha_{1 D}$ subunits, class $E$ calcium channels conduct transient calcium currents with rapid, voltage-dependent inactivation, and both activation and steady state inactivation occur at relatively negative membrane potentials (Soong et al., 1993; Williams et al., 1994). These characteristics are similar to a subset of relatively lowvoltage-activated calcium channels and suggest that class E calcium channels may initiate calcium-dependent action potentials in response to excitatory postsynaptic potentials at relatively negative membrane potentials. Because they have distinct physiological properties compared to previously studied classes of brain calcium channels, the subcellular localization of class $E$ calcium channels is of great interest. The distribution of class $\mathrm{E}$ calcium channels at varying levels in the cell bodies of neurons throughout the central nervous system suggests that they exert an important influcnce on cytosolic calcium levels and calciumdependent electrical events in the cell bodies of many central neurons. In addition to generating a transient depolarization of the cell body in response to lower threshold stimuli, they may provide calcium entry for general cellular processes such as gene expression, regulation of cellular signaling pathways, and control of membrane excitability.

The preferential staining of $\alpha_{1 \mathrm{E}}$ in cell somas is similar to the $\alpha_{1 \mathrm{C}}$ and $\alpha_{1 \mathrm{D}}$ subunits of L-type calcium channels (Ahlijanian et al., 1990, Westenbroek et al., 1990, Hell et al., 1993a). Similar to $\alpha_{1 \mathrm{D}}, \alpha_{1 \mathrm{E}}$ is distributed relatively smoothly over the cell surface in contrast to the patchy distribution of $\alpha_{1 \mathrm{C}}$. The distinct physiological properties of class $E$ channels may be important in initiating calcium-dependent action potentials in cell bodies and may provide a distinct pattern of calcium entry that is important in some aspects of neuronal regulation. The distribution of $\alpha_{1 \mathrm{E}}$ staining in the cell bodies also contrasts with our immunocytochemical studies using anti-peptide antibodies to the $\alpha_{1 \mathrm{~A}}$ and $\alpha_{1 \mathrm{~B}}$ subunits (Westenbroek et al., 1992, 1993, 1995) which exhibit little or no immunostaining on the cell soma of most neurons.

The staining of the cell body of most neurons by the CNE antibodies appears to fill the soma rather than just outline its periphery. This pattern is more noticeable for $\alpha_{1 E}$ than for other calcium channel classes, and is observed with both the antiCNE1 and anti-CNE2 antibodies and in both peroxidase-antiperoxidase and fluorescent visualization methods. In part, this staining pattern probably reflects the intracellular location of the epitopes against which the CNE antibodies were prepared. In addition, it is likely that pools of $\alpha_{1 \mathrm{E}}$ undergoing biosynthesis and processing in the endoplasmic reticulum and Golgi apparatus are also prominently stained and contribute to the intracellular staining. There may be a larger intracellular pool of $\alpha_{1 \mathrm{E}}$ precursors than for the other non-L-type calcium channel $\alpha_{1}$ subunits that we have studied. Direct identification of such an intracellular pool of $\alpha_{1 \mathrm{E}}$ and characterization of its role as a biosynthetic intermediate will require electron microscopic analysis of its localization and pulse-labeling studies of its metabolic fate.

The staining for $\alpha_{1 \mathrm{E}}$ in Purkinje neurons contrasts with electrophysiological studies which identify P-type current as the predominant calcium current in this cell (Mintz et al., 1992; Usowicz et al., 1992). However, these measurements were made in the cell body and large dendrites, while the most prominent immunostaining we observe is in the fine distal dendrites. These electrophysiological studies would not have detected calcium currents in the distal dendrites. Much of the cell body immunostaining that we observe with the anti-CNE antibodies is intracellular, so it is difficult to correlate with calcium current measurements. The development of selective blocker for class $\mathrm{E}$ calcium channels is needed to quantitate their contribution to the calcium current in Purkinje cell bodies more accurately.

\section{Localization of class $E$ calcium channels in dendrites}

Class E calcium channels are also strikingly localized in the dendrites of a distinct subset of CNS neurons. The distribution of $\alpha_{1 \mathrm{E}}$ immunoreactivity in dendrites appears to be more complex than for other channel types we have studied since dendrites are labeled in only certain nuclei and cell types. For example, in the hippocampus and the dorsal cortex there is barely detectable labeling of $\alpha_{1 \mathrm{E}}$ in proximal dendrites while in other regions, such as the olfactory bulb, the amygdala, and the cerebellum, there is intense $\alpha_{1 E}$ staining along the distal portions of the dendrites. This contrasts with our previous immunocytochemical studies in which high-voltagc-activated channels were localized along the entire length of dendrites of most neurons using antipeptide antibodies to $\alpha_{1 \mathrm{~B}}$ (Westenbroek et al., 1992) or $\alpha_{1 \Lambda}$ (Westenbroek et al., 1993, 1995).

Both low-voltage activated, transient calcium channels and high voltage-activated calcium channels are thought to be involved in the generation of calcium-dependent action potentials that are conducted along the length of dendrites (Llinas and Sugimori, 1979). The dendritic arbor of the cerebellar Purkinje neurons is an important site of calcium entry and electrogenesis in these neurons (Llinas and Sugimori, 1980; Tank et al., 1988). 
Recently, whole-cell patch-clamp recording combined with realtime confocal laser microscopy have revealed that stimulation of parallel fibers in the cerebellum results in a rise in intracellular calcium within the fine branches of the dendrites of Purkinjc cells (Eilers et al., 1994). Other studies in the cerebellum suggest that long-term depression of synaptic transmission is initiated by climbing fiber activation of voltage-gated calcium channels located on the dendrites of Purkinje neurons and by the subsequent rise in intracellular calcium postsynaptically (Konnerth et al., 1992; Ito et al., 1982). These responses were blocked by the AMPA-specific glutamate receptor blocker CNQX, and voltage clamp of the Purkinje cells was shown to reduce or eliminate the calcium signals. These findings suggested that these calcium signals arise from depolarization of the distal dendrites by activation of AMPA-specific glutamate receptors resulting in opening of voltage-gated calcium channels. Our immunoctyochemical studies suggest that these may be the class E calcium channels which we observed specifically localized at high density in the distal branches of the Purkinje cell dendrites.

We also observed an increased density of class $E$ immunoreactive calcium channels at branch points in Purkinje cell dendrites. A similar pattern of dendritic staining at branch points was observed with our antibody to $\alpha_{1 \mathrm{~B}}$ (Westenbroek et al., 1992) and by Fortier et al. (1991) using an anti- $\omega$-CTx GVIA antibody. This high concentration of calcium channels at dendritic branch points may contribute to the generation and conduction of calcium-dependent action potentials at these sites. In addition, ryanodine-sensitive and inositol triphosphate-activated intracellular calcium release channels appear to be more abundant at the main branch points of the Purkinje cell dendritic arbor (Ellisman et al., 1990; Walton et al., 1991) suggesting that the dendritic branch points play a vital role in the integration of dendritic signals which are calcium-dependent.

\section{Correlation between $\alpha_{I E}$ and native calcium channels}

Elcctrophysiological analyses of rat $\alpha_{1 \mathrm{E}}$ expressed in Xenopus oocytes, together with our ligand binding and immunolocalization data, demonstrate that $\alpha_{1 \mathrm{E}}$ exhibits distinct functional and pharmacological properties from L, N, P, and Q-type channels. $\alpha_{1 \mathrm{E}}$ has been proposed to be a "non-classic" low-voltage-activated calcium channel based on its relatively low threshold for voltage activation, fast kinetics of activation and inactivation, hyperpolarization-dependent repriming, high-affinity $\mathrm{Ni}^{2+}$ blockade (Soong et al., 1993), and permeation properties favoring $\mathrm{Ca}^{2+}$ over $\mathrm{Ba}^{2+}$ as a charge carrier (Bourinet et al., 1994). However, expression of structurally related $\alpha_{1}$ subunits from marine ray (Ellinor et al., 1993), rabbit (Wakamori et al., 1993), and human (Williams et al., 1994) have shown that the voltage dependence of activation of $\alpha_{1 \mathrm{E}}$-containing calcium channels can vary over a range of membrane potentials between those characteristic of low-voltage-activated and high-voltage-activated channels. While there are uncertainties inherent in comparing data from different expression protocols using different coexpressed auxiliary subunits, there are several previously described calcium currents with properties similar to those of the expressed $\alpha_{1 E}$ cDNA, including the R-type whole-cell calcium current of cerebellar granule neurons (Zhang et al., 1993), the G2 singlechannel current in cerebellar granule cells (Forti et al., 1994), calcium transients in the distal dendrites of ccrcbcllar Purkinje cells, as discussed above, and a novel transient calcium current in inhibitory neurons of the thalamic reticular nucleus (Huguenard and Prince, 1992). Our immunolocalization studies are con- sistent with a role for class $\mathrm{E}$ calcium channels in the transient calcium currents in the distal dendrites of cerebellar Purkinje cells and in thalamic reticular neurons, since we observe a substantial level of immunostaining for $\alpha_{1 E}$ in those locations. Staining of the cerebellar granule cells by the CNE antibodies is clearly detectable, but is less prominent than staining of many other classes of neurons. The R-type current represents approximately $15 \%$ of total calcium current in cerebellar granule neurons (Zhang et al., 1993). A strict quantitative correlation between immunostaining and current density is not expected because multiple calcium channels may contribute to the R-type current as presently defined, and alternative splicing may produce class $E$ calcium channels that are not recognized by our two antibodies. Therefore, the R-type whole-cell calcium current or the G2-type single-channel current in cerebellar granule neurons may also be due to class $\mathrm{E}$ calcium channels.

\section{References}

Ahlijanian MK, Westenbroek RE, Catterall WA (1990) Subunit structure and localization of dihydropyridine-sensitive calcium channels in mammalian brain, spinal cord, and retina. Neuron 4:819-832.

Armstrong DL, Rossier MF, Shcherbatko AD, White RE (1991) Enzymatic gating of voltage-gated calcium channels. Ann NY Acad Sci 635:26-34.

Bading H, Ginty DD, Greenberg ME (1993) Regulation of gene expression in hippocampal neurons by distinct calcium signaling pathways. Science 260:181-186.

Bean BP (1989) Classes of calcium channels in vertebrate cells. Annu Rev Physiol 51:367-384.

Birnbaumer L, Campbell KP, Catterall WA, Harpold MM, Hofmann F, Horne WA, Mori Y, Schwartz A, Snutch TP, Tanabe T, Tsien RW (1994) The naming of voltage-gated calcium channels. Neuron 13: 505-506.

Bourinet E, Stea A, Soong TW, Snutch TP (1994) Neuronal $\alpha_{1 E}$ calcium channels display permeation characteristics similar to low voltage activated channels. Soc Neurosci Abstr 20:70.

Brickey DA, Colbran RJ, Fong YL, Soderling TR (1990) Expression and characterization of the $\alpha$-subunit of $\mathrm{Ca}^{2+} /$ calmodulin-dependent protein kinase II using the baculovirus expression system. Biochem Biophys Res Commun 173:578-584.

Catterall WA (1994) Molecular properties of a superfamily of plasma membrane cation channels. Curr Opin Cell Biol 6:607-615.

Coppola T, Waldmann R, Borsotto M, Heurteaux C, Romey G, Mattei M-G, Lazdunski M (1994) Molecular cloning of a murine N-type channel $\alpha 1$ subunit: evidence for isoforms, brain distribution, and chromosomal localization. FEBS Lett 338:1-5.

Dolphin AC (1990) G protein modulation of calcium currents in neurons. Annu Rev Physiol 52:243-255.

Dubel SJ, Starr TVB, Hell J, Ahlijanian MK, Enyeart JJ, Catterall WA, Snutch TP (1992) Molecular cloning of the $\alpha 1$ subunit of an $\omega$-conotoxin-sensitive calcium channel. Proc Natl Acad Sci USA 89:50585062.

Eilers J-K, Augustine GJ, Konnerth A (1994) Subthreshold synaptic calcium signaling in dendrites and spines of cerebellar Purkinje neurons. Nature 373:155-158.

Ellinor PT, Zhang J-F, Randall AD, Zhou M, Schwarz TL, Tsien RW, Horne WA (1993) Functional expression of a rapidly inactivating neuronal calcium channel. Nature 363:455-458.

Ellisman MH, Deerinck TJ, Ouyang Y, Beck CF, Tanksley SJ, Walton PD, Airey JA, Sutko JL (1990) Identification and localization of ryanodine binding proteins in the avian central nervous system. Neuron $5: 135-146$.

Forti L, Tottene A, Moretti A, Pietrobon D (1994) Three novel types of voltage-dependent calcium channels in rat cerebellar neurons. $\mathrm{J}$ Neurosci 14:5243-5256.

Fortier L-P, Tremblay J-P, Rafrafi J, Hawkes R (1991) A monoclonal antibody to conotoxin reveals the distribution of a subset of calcium channels in the rat cerebellar cortex. Mol Brain Res 9:209-215.

Fujita Y, Mynlieff M, Dirksen RT, Kim MS, Niidome T, Nakai J, Freidrich T, Iwabe N, Miyata T, Furuichi T, Furutama D, Mikoshiba K, Mori Y, Beam KG (1993) Primary structure and functional expres- 
sion of the $\omega$-conotoxin-sensitive $\mathrm{N}$-type calcium channel from rabbit brain. Neuron 10:585-598.

Hell JW, Westenbroek RE, Warner C, Ahlijanian MK, Prystay W, Gilbert MM, Snutch TP, Catterall WA (1993a) Identification and differential subcellular localization of the neuronal class $C$ and class $D$ L-type calcium channel $\alpha 1$ subunits. J Cell Biol 123:949-961.

Hell JW, Yokoyama CT, Wong ST, Warner C, Snutch TP, Catterall WA (1993b) Differential phosphorylation of two size forms of the neuronal class C L-type channel. J Biol Chem 268:19451-19457.

Hell JW, Appleyard SM, Yokoyama CT, Warner C, Catterall WA (1994) Differential phosphorylation of two size forms of the N-type calcium channel $\alpha 1$ subunit which have different $\mathrm{COOH}$ termini. J Biol Chem 269:7390-7396.

Hell JW, Westenbroek RE, Elliott EM, Catterall WA (1995a) Differential phosphorylation, localization, and function of distinct $\alpha 1$ sybunits of neuronal calcium channels. Ann NY Acad Sci, in press.

Hell JW, Yokoyama CT, Breeze LJ, Chavkin C, Catterall WA (1995b) Phosphorylation of presynaptic and postsynaptic calcium channels by cAMP-dependent protein kinase in hippocampal neurons. EMBO J, in press.

Hirning LD, Fox AP, McCleskey EW, Olivera BM, Thayer SA, Miller RJ, Tsien RW (1988) Dominant role of $\mathrm{N}$-type $\mathrm{Ca}^{2+}$ channels in evoked release of norepinephrine from sympathetic neurons. Science 239:57-60.

Hofmann F, Biel M, Flockerzi V (1994) Molecular basis for $\mathrm{Ca}^{2+}$ channel diversity. Annu Rev Neurosci 17:399-418.

Huguenard JR, Prince DA (1992) A novel T-type current underlies prolonged $\mathrm{Ca}^{2+}$-dependent burst firing in GABAergic neurons of rat thalamic reticular nucleus. J Neurosci 12:3804-3817.

Hui A, Ellinor PT, Krizanova O, Wang J-J, Diebold RJ, Schwartz A (1991) Molecular cloning of multiple subtypes of a novel rat brain isoform of the $\alpha 1$ subunit of the voltage-dependent calcium channel. Neuron 7:35-44.

Hui SM, Raine L, Fanger H (1981) Use of avidin-biotin-peroxidase complex $(\mathrm{ABC})$ in immunoperoxidase techniques: a comparison between $\mathrm{ABC}$ and unlabeled antibody (PAP) procedures. J Histochem Cytochem 29:577-580.

Isom LL, DeJongh KS, Catterall WA (1994) Auxiliary subunits of voltage-gated ion channels. Neuron 12:1183-1194.

Ito M, Sakurai M, Tongroach P (1982) Climbing fibre induced depression of both mossy fibre responsiveness and glutamate sensitivity of cerebellar Purkinje cells. J Physiol (Lond) 324:113-134.

Kaczmarek LK, Jennings KR, Strumwasser F, Nairn AC, Walter U, Wilson FD, Greengard P (1980) Microinjection of catalytic subunit of cAMP-dependent protein kinase enhances calcium action potentials of bag cell neurons in cell culture. Proc Natl Acad Sci USA 77: 7487-7491.

Konnerth A, Dreesen J, Augustine GJ (1992) Brief dendritic calcium signals initiate long-lasting synaptic depression in cerebellar Purkinje cells. Proc Natl Acad Sci USA 89:7051-7055.

Laemmli UK (1970) Cleavage of structural proteins during assembly of the head of bacteriophage T4. Nature 227:680-685.

Llinas R, Sugimori M (1979) Calcium conductances in Purkinje cell dendrites: their role in development and integration. Prog Brain Res 51:323-334

Llinas R, Sugimori M (1980) Electrophysiological properties of in vitro Purkinje cell dendrites in manmualian cerebellar slices. J Physiol (Lond) 305:197-213.

Luebke JI, Dunlap K, Turner TJ (1993) Multiple calcium channel types control glutamatergic synaptic transmission in the hippocampus. Neuron 11:895-902.

Marubio LM, Miller RJ, Philipson LH (1994) Differential expression of $\alpha_{1 \mathrm{E}}$ calcium channel splice variants. Soc Neurosci Abstr 20:69.

McCleskey EW (1994) Calcium channels: cellular roles and molecular mechanisms. Curr Opin Neurobiol 4:304-312.

McLean IW, Nakane P (1974) Periodate-lysine-paraformaldehyde fixative for immunoelectron microscopy. J Histochem Cytochem 22: $1077-1083$.

Meriney SD, Gray DB, Pilar GR (1994) Somatostatin-induced inhibition of neuronal $\mathrm{Ca}^{2+}$ current modulated by cGMP-dependent protein kinase. Nature 369:336-339.

Merrifield RB (1963) Solid phase peptide synthesis. I. The synthesis of a tetrapeptide. J Am Chem Soc 85:2149-2154.

Mintz IM, Venema VJ, Swiderek KM, Lee TD, Bean BP, Adams ME
(1992) P-Type calcium channels blocked by the spider toxin $\omega$-AgaIVA. Nature 355:827-829.

Morgan JI, Curran T (1986) Role of ion flux in the control of c-fos expression. Nature 322:552-555.

Mori Y, Friedrich T, Kim MS, Mikami A, Nakai J, Ruth P, Bosse E, Hofmann F, Flockerzi V, Furuichi T, Mikoshiba K, Imoto K, Tanabe T, Numa $S$ (1991) Primary structure and functional expression from complementary DNA of a brain calcium channel. Nature 350:398402.

Murphy BJ, Catterall WA (1992) Phosphorylation of purified rat brain $\mathrm{Na}^{+}$channel reconstituted into phospholipid vesicles by protein kinase C. J Biol Chem 267:16129-16134.

Murphy TH, Worley PF, Baraban JM (1991) L-type voltage-sensirive calcium channels mediate synaptic activation of immediate early genes. Neuron 7:625-635.

Niidome T, Kim M, Friedrich T, Mori Y (1992) Molecular cloning and characterization of a novel calcium channel from rat brain. FEBS Lett 308:7-13.

Orth DN (1979) Methods of hormone radioimmunoassay, pp 245-284. New York: Academic.

Randall AD, Tsien RW (1995) Pharmacological dissection of multiple types of calcium channel currents in rat cerebellar granule neurons. J Neurosci 15:2995-3012.

Rotman EI, DeJongh KS, Florio V, Lai Y, Catterall WA (1992) Specific phosphorylation of a COOH-terminal site on the full-lengh form of the $\alpha 1$ subunit of the skeletal muscle calcium channel by cAMPdependent protein kinase. J Biol Chem 267:16100-16105.

Sather WA, Tanabe T, Zhang J-F, Mori Y, Adams ME, Tsien RW (1993) Distinctive biophysical and pharmacological properties of class A (B1) calcium channel $\alpha 1$ subunits. Neuron 11:291-303.

Sculptoreanu A, Scheuer T, Catterall WA (1993) Voltage-dependent potentiation of $\mathrm{L}$-type $\mathrm{Ca}^{2+}$ channels due to phosphorylation by cAMP-dependent protein kinase. Nature 364:240-243.

Snutch TP, Reiner PB (1992) $\mathrm{Ca}^{2+}$ channels: diversity of form and function. Curr Opin Neurobiol 2:247-253.

Snutch TP, Leonard JP, Gilbert MM, Lester HA, Davidson N (1990) Rat brain expresses a heterogeneous family of calcium channels. Proc Natl Acad Sci USA 87:3391-3395.

Snutch TP, Tomlinson WJ, Leonard JP, Gilbert MM (1991) Distinct calcium channels are generated by alternative splicing and are differentially expressed in the mammalian CNS. Ncuron 7:45-57.

Soong TW, Stea A, Hodson CD, Dubel SJ, Vincent SR, Snutch TP (1993) Structure and functional expression of a member of the low voltage-activated calcium channel family. Science 260:1133-1136.

Starr TVB, Prystay W, Snutch TP (1991) Primary structure of a calcium channel that is highly expressed in the rat cerebellum. Proc Natl Acad Sci USA 88:5621-5625.

Stea A, Tomlinson J, Soong TW, Bourinet E, Dubel SJ, Vincent SR, Snutch TP (1994a) Localization and functional properties of a rat brain $\alpha_{1 \mathrm{~A}}$ calcium channel reflect similarities to neuronal Q- and P-type channels. Proc Natl Acad Sci USA 91:10576-10580.

Stea $\Lambda$, Soong TW, Dubel SJ, Tomlinson WJ, Snutch TP (1994b) Activation of PKC selectively up-regulates both $\alpha_{1 \mathrm{E}}$ and $\alpha_{1 \mathrm{~B}}$ calcium channels. Soc Neurosci Abstr 20:1468.

Striessnig J, Glossman H, Catterall WA (1990) Identification of a phenylalkylamine binding region within the $\alpha 1$ subunit of skeletal muscle $\mathrm{Ca}^{2+}$ channels. Proc Natl Acad Sci USA 87:9108-9112.

Swartz KJ (1993) Modulation of $\mathrm{Ca}^{2+}$ channels by protein kinase $\mathrm{C}$ in rat central and peripheral neurons: disnuption of G-protein mediated inhibition. Neuron 11:305-320.

Takahashi T, Momiyama A (1993) Different types of calcium channels mediate central synaptic transmission. Nature 366:156-158.

Tank DW, Sugimori M, Connor JA, Llinas RR (1988) Spatially resolved calcium dynamics of mammalian Purkinje cells in cerebellar slice. Science 242:773-777.

Trautwein W, Hescheler J (1990) Regulation of cardiac L-type calcium current by phosphorylation and G-proteins. Annu Rev Physiol 52: 257-274.

Tsien RW, Ellinor PT, Horne WA (1991) Molecular diversity of voltage-dependent $\mathrm{Ca}^{2+}$ channels. Trends Pharmacol Sci 12:349-352.

Turner TJ, Adams ME, Dunlap K (1992) Calcium channels coupled to glutamate release identified by $\omega$-Aga-IVA. Science 258:310-313.

Turner TJ, Adams ME, Dunlap K (1993) Multiple $\mathrm{Ca}^{2+}$ channel types coexist to regulate synaptosomal neurntransmitter release. Proc Natl Acad Sci USA 90:9518-9522. 
Usowicz MM, Sugimori M, Cherksey B, Llinas R (1992) P-Type calcium channels in the somata and dendrites of adult cerebellar Purkinje cells. Neuron 9:1185-1199.

Wakamori M, Niidome T, Mori Y (1993) Functional expression of a novel type of calcium channel from cDNA. Soc Neurosci Abstr 19: 11.

Walton PD, Airey JA, Sutko JL, Beck CF, Mignery GA, Sudhof TC, Deerinck TJ, Ellisman MH (1991) Ryanodine and inositol trisphosphate receptors coexist in avian cerebellar Purkinje neurons. J Cell Biol 113:1145-1157.

Westenbroek RE, Ahlijanian MK, Catterall WA (1990) Clustering of L-type $\mathrm{Ca}^{2+}$ channels at the base of major dendrites in hippocampal pyramidal neurons. Nature 347:281-284.

Westenbroek RE, Hell JW, Warner C, Dubel SJ, Snutch TP, Catterall WA (1992) Biochemical properties and subcellular distribution of an $\mathrm{N}$-type calcium channel $\alpha 1$ subunit. Neuron 9:1099-1115.

Westenbroek RE, Hell JW, Sakurai T, Snutch TP, Catterall WA (1993) Immunocytochemical localization of class A calcium channels in adult rat brain. Soc Neurosci Abstr 19:1334.

Westenbroek RE, Sakurai T, Elliott EM, Hell JW, Starr TVB, Snutch TP, Catterall WA (1995) Immunochemical identification and subcellular distribution of the $\alpha_{1 \mathrm{~A}}$ subunits of brain calcium channels. J Neurosci 15:6403-6418.

Wheeler DB, Randall A, Tsien RW (1994) Roles of N-type and Q-type
$\mathrm{Ca}^{2+}$ channels in supporting hippocampal synaptic transmission. Science 264:107-111.

Williams ME, Feldman DH, McCue AF, Brenner R, Velicelebi G, Ellis SB, Harpold MM (1992a) Structure and functional expression of $\alpha 1$, $\alpha 2$, and $\beta$ subunits of a novel human neuronal calcium channel subtype. Neuron 8:71-84.

Williams ME, Brust PF, Feldman DH, Patthi S, Simerson S, Maroufi A, McCue AF, Velicelebi G, Ellis SB, Harpold MM (1992b) Structure and functional expression of an $\omega$-conotoxin-sensitive human $\mathrm{N}$-type calcium channel. Science 257:389-395.

Williams ME, Marubio LM, Deal CR, Hans M, Brust PF, Philipson LH, Miller RJ, Johnson EC, Harpold MM, Ellis SB (1994) Structure and functional characterization of neuronal $\alpha_{1 \mathrm{E}}$ calcium channel subtypes. J Biol Chem 269:22347-22357.

Woodgett JR, Hunter T (1987) Isolation and characterization of two distinct forms of protein kinase C. J Biol Chem 262:4836-4843.

Yang J, Tsien RW (1993) Enhancement of N- and L-type calcium channel currents by protein kinase $\mathrm{C}$ in frog sympathetic neurons. Neuron 10:127-136.

Zhang JF, Randall AD, Ellinor PT, Horne WA, Sather WA, Tanabe T, Schwarz TL, Tsien RW (1993) Distinctive pharmacology and kinetics of cloned neuronal $\mathrm{Ca}^{2+}$ channels and their possible counterparts in mammalian CNS neurons. Neuropharmacology 32:10751088. 